\title{
Dorota Gregorowicz
}

(University of Silesia in Katowice, Poland)

https://orcid.org/0000-0002-7443-7737

E-mail: dorota.gregorowicz@us.edu.pl

\section{Audiencja publiczna nuncjusza apostolskiego Galeazza Marescottiego na sejmie elekcyjnym 1669 r. Znaczenie i ceremoniał}

The Public Audience of the Apostolic Nuncio Galeazzo Marescotti at the Election Sejm of 1669, Its Significance and Ceremonial

\section{ABSTRACT}

Paying attention to the ceremonial aspects of the early modern diplomatic practice is one of the main postulates of the historians of diplomacy. The presented article focuses on the political circumstances and ceremonial manifestations of the participation of the apostolic nuncio Galeazzo Marescotti in a public audience at the election sejm of 1669, as a result of which Michał Korybut Wiśniowiecki was elected king. The Holy See's informational policy

\begin{tabular}{|c|c|c|c|c|}
\hline \multicolumn{5}{|c|}{ PUBLICATION INFO } \\
\hline I & UIMCS & : & $\begin{array}{l}\text { e-ISSN: } 2449-8467 \\
\text { ISSN: 2082-6060 }\end{array}$ & OPEN $\bigcirc A C C E S S$ \\
\hline \multicolumn{5}{|c|}{$\begin{array}{l}\text { THE AUTHOR'S ADDRESS: Dorota Gregorowicz, the Institute of History of the University of Silesia in Katowice, } \\
11 \text { Bankowa Street, Katowice } 40-007 \text {, Poland }\end{array}$} \\
\hline \multicolumn{5}{|c|}{$\begin{array}{l}\text { SOURCE OF FUNDING: Project of the National Science Centre in Poland, Sonatina 2, funds allocated pursuant } \\
\text { to the decision no. DEC-2018/28/C/HS3/00176, titled: „The Holy See and the crisis of sovereignty of John II } \\
\text { Casimir Vasa and Michael Korybut Wiśniowiecki's election (1660-1669)” }\end{array}$} \\
\hline \multicolumn{2}{|l|}{$\begin{array}{l}\text { SUBMITTED: } \\
2020.06 .23\end{array}$} & $\begin{array}{l}\text { ACCEPTED: } \\
\text { 2021.01.29 }\end{array}$ & $\begin{array}{l}\text { PUBLISHED ONLINE: } \\
\text { 2021.12.28 }\end{array}$ & (c) \\
\hline \multicolumn{3}{|c|}{$\begin{array}{l}\text { WEBSITE OF THE JOURNAL: } \\
\text { https://journals.umcs.pl/rh }\end{array}$} & $\begin{array}{l}\text { EDITORIAL } \\
\text { COMMITTEE E-mail: } \\
\text { reshistorica@umcs.pl }\end{array}$ & \multirow{2}{*}{8 Crossref dol } \\
\hline & & & ERIHPLUS & \\
\hline
\end{tabular}


regarding the political practice and ceremonial of the Polish-Lithuanian Commonwealth during the interregnum and the election period is discussed, especially in the emergence of a new interregnum in 1668, as a result of the abdication of John II Casimir Vasa. The papacy's diplomatic involvement towards the new election was at that time hampered by the cold relations between the nuncio and the ambitious primate of the Kingdom Mikołaj Prażmowski. The article also deals with the preparations for the nuncio's audience at the election sejm that took place from the beginning of May 1669, demonstrating the secondary nature of this event for the political life of the Commonwealth. Then, the diplomat's entry into the election field is presented, as is the detailed course of the audience, which culminated in the consigning of papal letters and the nuncio's oration. The noble reception of Marescotti's audience is also analysed. The article deals with the issues of political, diplomatic, and visual functions of the diplomatic audience. The hearing of the representative of the Holy See at the elective sejm is presented as an expression of the mutual belonging of the parties (the papacy and the PolishLithuanian Commonwealth) to the seventeenth-century European political order.

Key words: diplomacy, ceremonial, election, audience, nunciature

\section{STRESZCZENIE}

Zwrócenie uwagi na ceremonialne aspekty nowożytnej praktyki dyplomatycznej jest jednym z głównych postulatów współczesnych historyków dyplomacji. Prezentowany artykuł dotyczy okoliczności politycznych i przejawów ceremonialnych udziału nuncjusza apostolskiego Galeazza Marescottiego w audiencji publicznej na sejmie elekcyjnym 1669 r., w wyniku którego wybrany został na króla Michał Korybut Wiśniowiecki. Omówione zostają źródła informacji Stolicy Apostolskiej na temat praktyki politycznej i ceremoniału Rzeczypospolitej w okresie bezkrólewia i elekcji, szczególnie w kontekście nastania w 1668 r., w wyniku abdykacji Jana Kazimierza Wazy, niechcianego przez Rzym nowego bezkrólewia. Zaangażowanie dyplomatyczne papiestwa w obliczu nowej elekcji utrudniały wówczas chłodne relacje nuncjusza z ambitnym prymasem Mikołajem Prażmowskim. Artykuł porusza problem przygotowań do audiencji nuncjusza ze strony obradującego od początku maja 1669 r. sejmu elekcyjnego, demonstrując drugoplanowość tego wydarzenia dla życia politycznego Rzeczypospolitej. Przedstawiony zostaje następnie wjazd dyplomaty na pole elekcyjne oraz szczegółowy przebieg audiencji, której punkt kulminacyjny stanowiło przekazanie papieskich brewiów oraz oracja nuncjusza. Analizie poddano ponadto szlachecką recepcję posłuchania Marescottiego. W artykule podjęto problematykę politycznych, dyplomatycznych oraz widowiskowych funkcji audiencji dyplomatycznej. Posłuchanie przedstawiciela Stolicy Apostolskiej na sejmie elekcyjnym zaprezentowano jako wyraz obopólnej przynależności stron (papiestwa i Rzeczypospolitej) do europejskiego porządku politycznego XVII w.

Słowa kluczowe: dyplomacja, ceremoniał, elekcja, audiencja, nuncjatura

\section{Badanie barokowej etykiety, rytuałów i ceremonii dworskich stanowi dziś ważny element nowej historii dyplomacji ${ }^{1}$. Jeśli chodzi o aktywność}

1 Por. L. Bély, Souveraineté et souverains: la question du cérémonial dans les relations internationales à l'époque modern, "Annuaire-Bulletin de la Société de l'histoire de France" 1993, s. 27-43. 
służby dyplomatycznej Stolicy Apostolskiej, jest to aspekt o tyle ciekawy, że ukazuje specyfikę dualnego obrazu, w którym, poprzez badanie ceremoniału, z jednej strony określane są funkcje właściwe nuncjuszowi apostolskiemu lub legatowi papieskiemu $\mathrm{w}$ relacjach $\mathrm{z}$ ówczesnymi strukturami państwowymi, z drugiej natomiast - proces utrwalania i propagowania "międzynarodowej”2 tożsamości Stolicy Apostolskiej wobec trudności, jakie napotykała w XVII stuleciu realizacja idei papieskiego uniwersalizmu ${ }^{3}$. Jak zauważył badający siedemnastowieczny ceremoniał dyplomatyczny papiestwa Stefano Andretta: „na nacisk na ceremoniał, regulujący stosunki dyplomatyczne dużej części barokowego świata, nałożyła się dwoista, doczesna i duchowa, natura urzędu nuncjusza, który pomimo stopniowego upodabniania się do postaci dyplomaty świeckiego, wciąż stanowił o współistnieniu w tej samej swojej osobie regulatora i reorganizatora spraw kościelnych $\mathrm{z}$ jednej strony, $\mathrm{z}$ drugiej natomiast zarządcy relacji [Stolicy Apostolskiej] z władzą państwową. Koegzystencja obowiązków reprezentacji in temporalibus et in spiritualibus nadawała wysłannikom papieża szczególną rolę i traktowanie ceremonialne" ${ }^{4}$.

Przedmiotem niniejszego artykułu będzie analiza okoliczności politycznych oraz ceremoniału audiencji publicznej nuncjusza apostolskiego Galeazza Marescottiego na sejmie elekcyjnym 1669 r., w wyniku obrad którego królem obrany został Michał Korybut Wiśniowiecki. Bazę źródłową stanowić będzie korespondencja dyplomatyczna Stolicy Apostolskiej oraz diariusze sejmowe.

Potrzebę rozszerzenia badań nad audiencjami dyplomatów zagranicznych w Rzeczypospolitej epoki wazowskiej zasygnalizował niedawno Ryszard Skowron w swoim artykule o misji ambasadora Hiszpanii Francisca de Mendozy do Zygmunta III Wazy w 1597 r. ${ }^{5}$ Podejmując tego typu bada-

2 Słowo „międzynarodowa” umieszczam w cudzysłowie, rozumiejąc niedoskonałość tego pojęcia w odniesieniu do analizy stosunków politycznych nowożytnej Europy. Por. T.A. Sowerby, Early Modern Diplomatic History, „History Compass” 2016, 14, 9, s. 444.

3 Por. S. Andretta, Cerimoniale e diplomazia pontificia nel XVII secolo, w: Cérémonial et rituel à Rome: (16. ${ }^{\circ}-19 .^{\circ}$ siécle), red. M.A. Visceglia, C. Brice, Roma 1997, s. 201.

4 S. Andretta, op. cit., s. 201: "All'enfasi cerimonialistica che regolò i rapporti diplomatici di tanta parte del mondo barocco si sovrappose la doppia natura di carattere temporale e spirituale del nunzio, che, nonostante la progressiva aderenza alla figura del diplomatico secolare, vedeva pur sempre convivere nella stessa persona la sorveglianza e la riorganizzazione ecclesiastica da un lato e dall'altro la gestione dei rapporti con il potere civile. La coesistenza di doveri di rappresentanza in temporalibus et in spiritualibus conferiva naturalmente agli inviati del papa un ruolo e un cerimoniale peculiari". Por. P. Prodi, Diplomazia del Cinquecento. Istituzioni e prassi, Bologna 1963, s. 128 i n. Wszystkie zawarte w artykule tłumaczenia zostały wykonane przez autorkę.

5 R. Skowron, Ceremoniat przyjęcia ambasadora hiszpańskiego Francisca de Mendozy na warszawskim dworze Wazów w roku 1597, „Kronika Zamkowa” 2017, 70, 4, s. 25. 
nia, należy wziąć pod uwagę rozbudowaną strukturę przestrzenno-organizacyjną nowożytnego państwa polsko-litewskiego, w którym ceremonialne interakcje miały, w porównaniu do siedemnastowiecznej Europy, swoją charakterystyczną lokalną specyfikę, związaną z metodami prowadzenia przez Rzeczpospolitą polityki zagranicznej, z procesem sejmowania, a także z kulturą szlachecką.

\section{PROBLEM PRECEDENCJI NUNCJUSZA APOSTOLSKIEGO NA TLE RYWALIZACJI Z PRYMASEM MIKOŁAJEM PRAŻMOWSKIM}

Popierany przez Stolicę Apostolską od początku lat sześćdziesiątych XVII w. program reform ustrojowych, a przede wszystkim wprowadzenie elekcji vivente rege, okazały się nie do zrealizowania w zaistniałych wówczas w Rzeczypospolitej warunkach politycznych. Fiaskiem zakończyły się również ówczesne papieskie starania o doprowadzenie do ponownego małżeństwa Jana Kazimierza Wazy i tym samym, przynajmniej tymczasowe rozwiązanie problemów związanych z kontynuacją rządów monarchy. Pod koniec maja 1668 r. do Rzymu dotarła wiadomość o ostatecznym zamiarze złożenia korony przez Wazę . Zdecydowanie przeciwny tym planom Klemens IX już od dłuższego czasu wielokrotnie odradzał polsko-litewskiemu monarsze rezygnację z tronu ${ }^{8}$. Działania podjęte przez dyplomację papieską celem zapobieżenia jego abdykacji spoczęły w głównej mierze na barkach ówczesnych nuncjuszy apostolskich w Rzeczypospolitej: tytularnego arcybiskupa Larissy Antonia Pignatelliego (do maja

6 Jan Kazimierz Waza do Klemensa IX, Warszawa 30 V 1668, w: Vetera monumenta Poloniae et Lithuaniae gentiumque finitimarum historiam illustrantia, t. 3, 1585-1696, wyd. A. Theiner, Roma 1863, nr CLXXV, s. 568-569; Jan Kazimierz Waza do V. Orsiniego, Warszawa 30 V 1668, w: Elementa ad Fontium Editiones, t. 3, Repertorium rerum polonicarum ex Archivo Orsini in Archivo Capitolino Romae, I pars, wyd. W. Wyhowska de Andreis, Romae 1961, nr 571, s. 62.

7 W. Seredyński, Sprawa obioru nastepcy na tron za panowania i po abdykacyi Jana Kazimierza, Kraków 1864, s. 75; M. Matwijów, Geneza abdykacji Jana Kazimierza Wazy 1662-1668, „Czasopismo Zakładu Narodowego imienia Ossolińskich” 2000, 11, s. 128; D. Gregorowicz, Stolica Apostolska wobec abdykacji Jana Kazimierza, "Kronika Zamkowa” 2015, 68, 2, s. 139-161.

8 Stolicy Apostolskiej nie zależało bezpośrednio na utrzymaniu Jana Kazimierza na tronie. Ostatni z polskich Wazów nie był zresztą darzony w Rzymie szczególną sympatią. Zmiana na tronie Rzeczypospolitej w osobie katolickiego księcia, takiego jak na przykład Filip Wilhelm Neuburg, zostałaby przez Rzym przyjęta pozytywnie. Wszelkie podjęte przez Stolicę Apostolską działania, mające na celu odwiedzenie Jana Kazimierza od abdykacji, wynikały z obaw przed ryzykiem politycznym, jakie niosło ze sobą bezkrólewie, szczególnie w tak trudnej sytuacji, w jakiej znalazła się Rzeczpospolita u schyłku panowania ostatniego z Wazów. Zob. D. Gregorowicz, Stolica, s. 160. 
1668 r.), a następnie tytularnego arcybiskupa Koryntu Galeazza Marescottiego. W sprawę zaangażował się również kardynał protektor Virginio Orsini, działający na terenie państwa polsko-litewskiego za pośrednictwem swoich agentów. Ponadto, w przededniu złożenia przez Jana Kazimierza korony, w Kurii rzymskiej poważnie rozważano projekt wysłania do Rzeczypospolitej papieskiego legata a latere, wysunięty przez samego abdykującego monarchę; nie przybrał on jednak wówczas konkretnego kształtu. Zagadnienie legacji powrócić miało jednak do dyplomatycznych kuluarów bezpośrednio po abdykacji króla, w obliczu nieuchronnie zbliżającego się nowego sejmu elekcyjnego'.

U progu interregnum, zainaugurowanego oficjalnie w wyniku abdykacji Jana Kazimierza w dniu 16 września 1668 r. ${ }^{10}$, powszechnie wiadomo już było, że nie dojdzie do skutku planowana w ciagu kilku ostatnich miesięcy (praktycznie od zakończenia obrad sejmu 1668 r.) ekspedycja papieskiego legata a latere na zbliżający się sejm elekcyjny. Tymczasem przybyły do Rzeczypospolitej w czerwcu 1668 r. nuncjusz apostolski Marescotti nie potrafił nawiązać dobrych stosunków z ambitnym prymasem Mikołajem Prażmowskim, niezwykle zazdrosnym o własne prerogatywy i status legato nato. „Uważam za konieczne poinformowanie Waszej Eminencji o trudnościach, jakie napotkam, chcąc zająć w Senacie miejsce, które uważa się, że zajmował arcybiskup De Torres ${ }^{11} \mathrm{~W}$ ostatnim Interregnum"12 alarmował w tym kontekście rzymski Sekretariat Stanu nuncjusz apostolski, przedstawiając już wówczas swoje obawy w związku z przebiegiem nadchodzącego sejmu elekcyjnego. Niepokój Marescottiego wzbudzała

9 D. Gregorowicz, Primate Mikołaj Prażmowski and the Unwelcome Papal Legation in Poland-Lithuania (1668-1669), „Legatio: the Journal for Renaissance and Early Modern Diplomatic Studies" 2018, 2, s. 29-63.

10 Geneza abdykacji Jana Kazimierza oraz sejm 1668 r. zostały szczegółowo opracowane przez M. Matwijowa (Ostatnie sejmy przed abdykacja Jana Kazimierza 1667 i 1668 , Wrocław 1992; Geneza abdykacji Jana Kazimierza). Na sejmie abdykacyjnym i reakcjach społecznych wobec aktu cesji korony skupił się W. Kłaczewski (Abdykacja Jana Kazimierza. Społeczeństwo szlacheckie wobec kryzysu politycznego lat 1667-1668, Lublin 1993), natomiast stanowisko senatu koronnego wobec abdykacji opracował J. Dąbrowski (Senat koronny wobec abdykacji Jana Kazimierza, "Zeszyty Naukowe Uniwersytetu Jagiellońskiego. Prace Historyczne" 2000, 127, s. 39-58). Cennym dla badań nad abdykacją pozostaje klasyczny szkic W. Czermaka (Ostatnie lata życia Jana Kazimierza, w: Ostatnie lata Jana Kazimierza, oprac. A. Kersten, Warszawa 1972, s. 257-447). Postawę papiestwa wobec abdykacji opisała D. Gregorowicz (Stolica, s. 139-161).

11 Arcybiskup tytularny Adrianopola Giovanni de Torres (1605-1662), nuncjusz apostolski w Rzeczypospolitej w latach 1645-1652.

12 Archivio Apostolico Vaticano [dalej: AAV], Segr. di Stato, Polonia 82, k. 442r, G. Marescotti do G. Rospigliosiego, Warszawa, 7 XI 1668: „Stimo necessario partecipare hora all'Eminenza Vostra la difficoltà che io incontrarò nell'havere in publico Senato il posto, che si suppone havesse Mons. De Torres nell'ultimo Interregno". 
przede wszystkim wyniosłość prymasa Prażmowskiego, ale także przewidywana absencja sędziwego arcybiskupa lwowskiego Jana Tarnowskiego, w wyniku której nuncjusz miałby zająć miejsce u boku arcybiskupa gnieźnieńskiego, a nie centralne, ponad obydwoma metropolitami ${ }^{13}$.

$\mathrm{W}$ istocie było się o co niepokoić, ponieważ wystąpienie papieskiego dyplomaty na obradach zbliżającego się sejmu elekcyjnego planowane było już wiele miesięcy przed jego inauguracją. W Kurii rzymskiej skrupulatnie analizowano poprzednie przypadki elekcji (przede wszystkim tej ostatniej, z 1648 r., ale sięgano również do wcześniejszych relacji), okoliczności wystąpień papieskich dyplomatów, charakter ceremonialny ich audiencji, a także treść wygłaszanych oracji. W 1669 r. urzędnicy papieskiego Sekretariatu Stanu przeprowadzili w tym zakresie uważne poszukiwania w Archiwum św. Piotra, a zatem pierwszej instytucji systematycznie magazynującej papieskie akta. Tam, w dokumentacji nuncjatury Giovanniego de Torresa (1645-1652), odnaleziono relację zawierającą opis ceremoniału audiencji publicznej nuncjusza na sejmie elekcyjnym 1648 r., którego kopia została następnie bezzwłocznie przesłana aktualnemu papieskiemu reprezentantowi w Rzeczypospolitej, Marescottiemu ${ }^{14}$. Kardynał Sekretarz Stanu Giacomo Rospigliosi podkreślił również wagę relacji w tym zakresie uczynionych przez pochodzącego z Lukki krakowskiego kupca i erudyty Girolama Pinocciego, il quale notava ogni cosa per farne historia ${ }^{15}$. Wiadomości na temat przebiegu elekcji 1648 r. dostarczali Kurii rzymskiej również ówczesny Komisarz Kamery Apostolskiej Giacomo Fantuzzi ${ }^{16}$, który pełnił wcześniej funkcje audytora nuncjatury De Torresa, a także

13 Ibidem, k. 442. Por. AAV, Segr. di Stato, Polonia 82, k. 529, G. Marescotti do G. Rospigliosiego, Warszawa, 9 I 1669. Takie było przekonanie nuncjusza, ale w praktyce miejsce arcybiskupa lwowskiego zajmował wówczas biskup krakowski i tak też stało się na elekcji 1669 r.

14 Kopia tej relacji znajduje się obecnie pod sygnaturą AAV, Segr. di Stato, Polonia 182, k. 89v-90, G. de Torres do G. Panciroliego, Warszawa, 31 X 1668. Por. AAV, Segr. di Stato, Polonia 182, k. 95-96r, G. Rospigliosi do G. Marescottiego, Rzym, 17 XI 1668; AAV, Segr. di Stato, Polonia 82, k. 73r, G. Rospigliosi do G. Marescottiego, Rzym, 8 XII 1668.

15 AAV, Segr. di Stato, Polonia 182, k. 89, G. Rospigliosi do G. Marescottiego, Rzym, 17 XI 1668. Na temat Girolama Pinocciego zob. R. Mazzei, Edycje florenckie i lukańskie $w$ krakowskiej bibliotece w XVII wieku, "Odrodzenie i Reformacja w Polsce” 2011, 55, s. 219-222.

16 AAV, Segr. di Stato, Polonia 82, k. 68r, G. Rospigliosi do G. Marescottiego, Rzym, 17 XI 1668. Na temat G. Fantuzziego zob. P. Marchesani, La Polonia nei diari di viaggio di Giacomo Fantuzzi, Warszawa 1977; G. Fantuzzi, Diariusz podróży po Europie (1652), oprac. i tłum. W. Tygielski, Warszawa 1990; R. Cascioli, Fantuzzi, Giacomo, w: Dizionario Biografico degli Italiani [dalej: DBI], t. 44, 1994, https://www.treccani.it/enciclopedia/giacomofantuzzi_(Dizionario-Biografico) [dostęp: 1 VI 2020]; W. Tygielski, Włosi w Polsce XVI-XVII wieku, Warszawa 2005, s. 328. 
przebywający w Rzeczypospolitej sekretarz Jana Kazimierza, Cristoforo Masini ${ }^{17}$. W listopadzie 1668 r. kardynał Rospigliosi wymieniał ponadto senatorów, którzy powinni byli pamiętać wydarzenia sprzed dwudziestolecia i audiencję publiczną De Torresa na sejmie elekcyjnym 1648 r. Pośród wspomnianych osobistości znaleźli się prymas Prażmowski, biskup krakowski Andrzej Trzebicki, a także biskup płocki Jan Gembicki ${ }^{18}$.

Ostatecznie jednak najwięcej informacji na temat okoliczności elekcji 1648 r., a przede wszystkim udziału weń nuncjusza apostolskiego, odnaleziono $\mathrm{w}$ dokumentacji nuncjatury De Torresa; zdecydowanie mniej $\mathrm{z}$ nich pochodziło natomiast $\mathrm{z}$ relacji przedstawicieli polsko-litewskiej sceny politycznej. „,To naprawdę dziwne, że spośród wielu ludzi aktywnych w czasach Monsiniora De Torresa, na sejmie nie ma nikogo, kto pamiętałby tak uroczyste wydarzenie"19 - irytował się kardynał Sekretarz Stanu Rospigliosi. Nie mogło to być jednak aż tak zaskakujące, szczególnie biorąc pod uwagę obawy prymasa Prażmowskiego przed koniecznością udzielenia papieskiemu dyplomacie ceremonialnego pierwszeństwa; jeśli chodzi natomiast o relacje innych członków episkopatu, mogli oni po prostu obawiać się narażenia, poprzez swoje zeznania, osobie prymasa.

Na początku 1669 r. nuncjuszowi w Rzeczypospolitej udało się jednak zdobyć w końcu zaufanie i nawiązać współpracę ze świadkami elekcji Jana Kazimierza z 1648 r. in loco: „Przesłuchani przeze mnie na osobności, pod pozorem [mojej] ciekawości, biskupi krakowski [Trzebicki] i płocki Gembicki (wówczas [w 1648 r.] wielki sekretarz [koronny]), a także pan Masini i pan Pinocci, Lukkańczyk, którzy nie przyjaźnią się zbytnio z arcybiskupem gnieźnieńskim, szczerze mówiąc cała czwórka odpowiedziała mi tak samo, to znaczy, że Monsinior De Torres pozostawił w Rzymie relację, według której [podczas swej audiencji na sejmie elekcyjnym] objął miejsce na czele koła pomiędzy dwoma arcybiskupami" 20 - relacjonował Marescotti.

17 D. Caccamo, Osservatori italiani della crisi polacca a metà del Seicento. La Relazione di s. Cefali e le Replicazioni di C. Masini, "Archivio Storico Italiano” 1974, 71, s. 309-370; K. Targosz, Masini, Krzysztof, w: Polski Słownik Biograficzny, t. 20, Wrocław-Gdańsk 1975, s. 117-119; L. Ronchi De Michelis, Masini, Cristoforo, w: DBI, t. 71, 2008, https://www.treccani. it/enciclopedia/cristoforo-masini_\%28Dizionario-Biografico\%29/[dostęp: 1 VI 2020].

18 AAV, Segr. di Stato, Polonia 182, k. 89, G. Rospigliosi do G. Marescottiego, Rzym, 17 XI 1668; AAV, Segr. di Stato, Polonia 82, k. 68r, G. Rospigliosi do G. Marescottiego, Rzym, 17 XI 1668. Zob. D. Gregorowicz, Primate, s. 51.

19 AAV, Segr. di Stato, Polonia 182, k. 95r, G. Rospigliosi do G. Marescottiego, Rzym, 9 II 1669: „E cosa veramente strana che di tante persone intervenute nel tempo di Mons. De Torres alla Dieta non vi sia chi tenga memoria di un fatto così solenne".

20 AAV, Segr. di Stato, Polonia 82, k. 529v-530r, G. Marescotti do G. Rospigliosiego, Warszawa, 9 I 1669: „Interrogatine da me separatamente, come per modo di curiosità, 
Na podstawie posiadanych informacji w Rzymie nieustannie starano się zatem podkreślać wyższość ceremonialną papieskiego dyplomaty nad prymasem - legato nato Rzeczypospolitej. Nacisk na tę kwestię był oczywisty, biorąc pod uwagę konflikty na tle precedencji stale narastające pomiędzy aktualnym nuncjuszem Marescottim a Prażmowskim (które nasiliły się już podczas sejmu abdykacyjnego Jana Kazimierza), a także niechęć i obawy prymasa wobec projektów przyjęcia legacji kardynalskiej z okazji

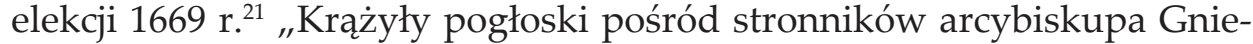
zna, że miejscem zwykłym dawać nuncjuszowi na sejmie [elekcyjnym] jest to samo, jak to przydawane innym ambasadorom, to znaczy u stóp koła" ${ }^{22}$ - ostrzegał Marescotti. Na obawy nuncjusza odpowiadano jednak z Rzymu w sposób zdecydowany: „Nawet w najdawniejszych czasach pobożność Rzeczypospolitej i jej godna cześć w stosunku do Najwyższego Papieża przydawały jeszcze większego uznania prerogatywom nuncjatury apostolskiej na sejmach elekcyjnych, a arcybiskupi prymasi zawsze [w tym duchu] chcieli się wykazać, w sposób szczególny honorując tego, który reprezentuje samego Papieża" ${ }^{23}$.

Ostatecznie, wersja zasad precedencji i ceremoniału, jakie powinny obowiązywać nuncjusza na audiencji publicznej podczas zbliżającego się sejmu elekcyjnego została w Rzymie określona w następujący sposób: „Podczas sejmów biskupi nie zasiadają wszyscy po jednej stronie [szopy], jak być może przypuszczał Wasza Eminencja, ale po obydwu stronach jednakowo. $W$ ten sposób, biskupi zajmują wszystkie pierwsze miejsca wzdłuż owalnego kręgu po jednej stronie, i po drugiej, udzielając nuncjuszowi podczas interregnum miejsca na czele kręgu, pośrodku dwóch arcybiskupów. [Dlatego] Monsinior arcybiskup gnieźnieński w żaden sposób nie może pretendować do zajmowania pierwszego miejsca na cze-

li Monsignori Vescovi di Craccovia, e Vescovo di Plosca Gembischi, all'hora Gran Segretario, et ancora il Sig. Masini et il Sig. Pinocci Gentilhuomo Lucchese, li quali non sono molto amici di Mons. Arcivescovo di Gnesna, francamente tutti quattro mi risposero lo stesso, cioè che Mons. De Torres haveva data relatione a Roma di haver havuto il luogo in capo del circolo, fra li due Arcivescovi".

21 D. Gregorowicz, Primate, s. 29-63.

22 AAV, Segr. di Stato, Polonia 182, k. 529, G. Marescotti do G. Rospigliosiego, Warszawa, 9 I 1669: „Si vociferava da' parziali di Mons. Arcivescovo di Gnesna, che il luogo solito darsi al Nunzio in detta Dieta era quello stesso degli altri Ambasciatori, cioè a' piedi del circolo".

23 AAV, Segr. di Stato, Polonia 182, k. 95, G. Rospigliosi do G. Marescottiego, Rzym, 17 XI 1668: „Ancorché ne' tempi più antichi la pietà della Republica di Polonia e la sua degna venerazione verso il Sommo Pontefice habbia con maniera ancora di maggior decoro dato nelle Diete d'Interregno luogo, e prerogative a' Nunzi Apostolici, e gli Arcivescovi Primati habbian sempre voluto dimostrarsi tali, specialmente nell'honorare al maggior segno chi rappresenta principalmente il Papa". 
le duchowieństwa, z poprzedzeniem nuncjusza, co być może byłoby możliwe, gdyby duchowieństwo stało po jednej stronie [kręgu]"24. Marescotti, podobnie jak przed dwudziestu laty De Torres, miał zatem zająć miejsce pomiędzy dwoma arcybiskupami, w delikatnym odstępie $\mathrm{w}$ stosunku do pozostałych członków episkopatu. „Nie mając żadnych wątpliwości co do prawdomówności relacji Monsiniora Torresa - naciskał kardynał Sekretarz Stanu Rospigliosi - Jego Świątobliwość uważa że powinien Waszmość nieustannie nalegać, aby być traktowanym tak samo, jak on, lub przynajmniej w inny, podobny sposób" 25 .

Pomimo tych wyraźnych wytycznych, nuncjusz obawiał się, że w relacjach z Prażmowskim na nic zdadzą się utarte zasady ceremonialne i relacje z poprzednich elekcji, autoryzowane przez papieski Sekretariat Stanu, a wszystko to zweryfikowane zostanie przez lokalne układy sił i politykę prymasa. Według Marescottiego, nawet jeśli i w samej Rzeczypospolitej definitywnie potwierdzone i zaakceptowane zostałoby ceremonialne pierwszeństwo nuncjusza, prymas raczej nie zjawi się na obradach sejmu elekcyjnego w dniu audiencji papieskiego dyplomaty, niż faktycznie udzieli mu precedencji, „udając niedyspozycję, lub wyraźne oświadczając, że robi to, aby ustąpić mi [nuncjuszowi] godniejszego miejsca" ${ }^{26}$. W związku z tym, celem wzmocnienia pozycji papieskiego dyplomaty w Rzeczypospolitej, zostały mu przesłane w tej sprawie z Rzymu specjalne listy (w aż czterech wersjach, w zależności od tego, którym chciałby się w danych okolicznościach posłużyć Marescotti), potwierdzające tradycyjną procedurę wystąpień dyplomatów papieskich na sejmach elekcyjnych $\mathrm{w}$ formie audiencji publicznych. W Rzymie za podstawowe zagrożenie dla jej zachowania zgodnie uznano osobę Prażmowskiego i prowadzoną przezeń politykę. Nuncjuszowi w Rzeczypospolitej polecano, żeby, jeśli prymas odmówiłby respektowania tradycyjnych prerogatyw i preceden-

24 AAV, Segr. di Stato, Polonia 82, k. 529v-530r, G. Marescotti do G. Rospigliosiego, Warszawa, 9 I 1669: „L'Ordine Episcopale nelle Diete non sta tutto da una parte, come forse Vostra Eminenza havrà supposto, ma da ambedue le parti egualmente, sì che li Vescovi tengono tutti li primi luoghi del Circolo ovalo dall'una parte, e l'altra. Onde dandosi al Nunzio nell'Interregno il luogo in capo del Circolo, in mezo alli due Arcivescovi, non può in alcun modo Mons. Arcivescovo di Gnesna lusingarsi di haver havuto il primo luogo come capo dell'Ordine Ecclesiastico, et haver preceduto al Nunzio, il che forse militarebbe, se l'Ordine Episcopale stesse tutto da una parte".

25 AAV, Segr. di Stato, Polonia 82, k. 74, G. Rospigliosi do G. Marescottiego, Rzym, 8 XII 1669: „Essendo dunque il fatto di Mons. Torres vero fuor d'ogni dubio, stima Sua Santità che deva Vostra Signoria insistere constantemente per havere il medesimo trattamento che egli hebbe, o altro eguale almeno".

26 AAV, Segr. di Stato, Polonia 82, k. 531r, G. Marescotti do G. Rospigliosiego, Warszawa, 9 I 1669: „O fingendosi indisposto, o dichiarandosi espressamente di farlo per dar campo a me che goda il luogo più degno”. Zob. D. Gregorowicz, Primate, s. 49. 
cji nuncjusza, zaszantażować go, ujawniając treść korespondencji, z której wynikało, że to z winy Prażmowskiego, podyktowanej wybujałą ambicją i egocentryzmem, planowana misja kardynała legata do Rzeczypospolitej na okres bezkrólewia i elekcji 1669 r. (której projekt był mile widziany przez przeważającą część szlacheckiej opinii publicznej) zakończyła się fiaskiem ${ }^{27}$. Jeśli biskupi krakowski Trzebicki i płocki Gembicki przychyliliby się do wersji przedkładanej przez prymasa, nuncjusz miał się posłużyć listem, w którym nie było mowy o ich świadectwie. Jeżeli natomiast potwierdziliby oni wersję papieska, należało przedstawić list, w którym powoływani byli oni na świadków. Tych natomiast, którzy nie mieli wiedzy na temat wydarzeń poprzedniego interregnum i elekcji, papieskie listy przekonać miały do uznania wersji podawanej przez Sekretariat Stanu Klemensa IX, reprezentujący niepodważalny autorytet Stolicy Apostolskiej. Prażmowski nie mógł zatem de facto przeciwstawić się papieskiej wersji procedury i ceremoniału wystąpienia reprezentanta Stolicy Apostolskiej na nadchodzącym sejmie bez uciekania się do rozwiązań siłowych i pogłębiania istniejącego już od miesięcy konfliktu na linii prymas - dyplomacja papieska. Liczono jednak na to (i słusznie), że ze względu na tradycyjną lojalność i szacunek okazywany w Rzeczypospolitej Stolicy Apostolskiej, arcybiskup gnieźnieński nie odważy się na podjęcie podobnego kroku. W każdym razie, jeśli pozycja ceremonialna i autorytet papieskiego dyplomaty w państwie polsko-litewskim miałyby być w związku $\mathrm{z}$ nadchodzącym wyborem nowego monarchy w jakimkolwiek stopniu zagrożone, z Rzymu polecano nuncjuszowi, aby na sejmie elekcyjnym nie przystępował do audiencji publicznej, przesyłając nań jedynie, za pośrednictwem osób trzecich, papieskie brewia. Absencja nuncjusza na sejmie elekcyjnym mogła faktycznie zaistnieć w dwóch rodzajach okoliczności: towarzysząc otwartej deklaracji, iż reprezentantowi Stolicy Apostolskiej nie zostało przydzielone przysługujące mu miejsce odpowiadające tradycyjnym zasadom precedencji, lub też pod pozorem chwilowej niedyspozycji dyplomaty (zdrowotnej, lub innego rodzaju). Ponadto nuncjusz, poprzez przeprowadzenie odpowiednich przygotowań dyplomatycznych, mógł też postarać się o to, aby to sam senat wystosował doń prośbę o nie interweniowanie na obradach sejmu elekcyjnego (tu oficjalnie podawane ku temu powody mogły być różne). W powyższym zakresie pozostawiono Marescottiemu wolną rękę. Miał on samodzielnie ocenić, przyjęcie której z argumentacji w przypadku absencji na obradach sejmu elekcyjnego byłoby najkorzystniejsze dla autorytetu Stolicy Apostolskiej, szczególnie

27 D. Gregorowicz, Primate, s. 29-63. 
w perspektywie kontynuacji przez arcybiskupa Koryntu urzędu nuncjusza w Rzeczypospolitej u boku nowego monarchy ${ }^{28}$.

\section{PRZYGOTOWANIA DO PUBLICZNEJ AUDIENCJI NUNCJUSZA NA SEJMIE ELEKCYJNYM}

Marescotti podkreślał powolność obrad toczących się w pierwszych tygodniach trwania sejmu elekcyjnego 1669 r. Przynajmniej do dnia 21 maja, tłumacząc się trwającymi rozstrzygnięciami sądów kapturowych (określanymi przez nuncjusza jako sprawa, „która powinna poprzedzać każdą czynność, dla bezpieczeństwa publicznego" ${ }^{29}$ ), nie podejmował on jeszcze tematu swojej audiencji publicznej w sejmowych kuluarach. Prymas Prażmowski w senacie i marszałek poselski Szczęsny Kazimierz Potocki w kole przedłożyli po raz pierwszy sprawę posłuchań posłów zagranicznych w dniu 22 maja $^{30}$. Została ona tego samego dnia poruszona także w wystąieniu podkomorzego krzemienieckiego Stefana Ledóchowskiego, który podkreślił jednak priorytetowość wcześniejszego zamknięcia sprawy egzorbitancji ${ }^{31}$. W związku z tym, po zakończeniu kapturów, w dniu 23 maja, Marescotti posłał do prymasa Prażmowskiego, do marszałka wielkiego koronnego Jana Sobieskiego oraz do marszałka sejmu Potockiego swojego sekretarza z informacja, iż powinien on przedstawić zgromadzonej szlachcie brewia skierowane do niej przez Klemensa IX, a następnie ustnie zaświadczyć o nieustającej opiece Stolicy Apostolskiej nad Rzecząpospolitą. Nuncjusz poprosił tym samym o udzielenie mu

28 AAV, Segr. di Stato, Polonia 82, k. 76, G. Rospigliosi do G. Marescottiego, Rzym, 8 XII 1668. Zob. też AAV, Segr. di Stato, Polonia 82, k. 74v-75, G. Rospigliosi do G. Marescottiego, Rzym, 8 XII 1668.

29 AAV, Arch. Nunz. di Varsavia 174, k. 102v, Breve relatione dell'Udienza publica di Monsignor Nontio nella Dieta d'Elettione a dì 4 Giugno 1669: "Qual deve precedere ogn'altro affare per publica sicurezza".

30 Biblioteka Zakładu Narodowego im. Ossolińskich [dalej: BO], rkps 239/III, k. 27r, Diariusz sejmu elekcyjnego króla Michała Korybuta Wiśniowieckiego w 1669 r.; Biblioteka Książąt Czartoryskich [dalej: BC], rkps 164, k. 171, Diariusz Wolnej Elekcji na Pana Nowego post Abdicationem Regni Serenissimi Joannes Casimiri Regis Poloniae 1669; BC, rkps 408, k. 558, Diariusz Elekcji Króla Michała. Według Biblioteka Kórnicka [dalej: BK], rkps 316, k. 308v, Diariusz sejmu electionis 1669, miało to miejsce już 21 maja: „[Prymas] Ksiądz Jego Mość uczynił proloquim do czytania Senatus Consultorum interregni, invitando Ichmościów do słuchania, namieniając, aby Ichmoście naznaczali czas audiencjom posłów cudzoziemskich, którzy się o to przykrzą".

31 BC, rkps 404, k. 51, Diariusz Sejmu Elekcji po złożeniu korony przez Jana Kazimierza 2 Maja 1669 zaczęty, przez Chojnackiego opisany; BK, rkps 365, k. 9r, Connotatio transactionum na elekcji warszawskiej novi principis, utinam feliciter regnantis [...] 1669. 
audiencji publicznej w dniu, który polsko-litewskim dygnitarzom wyda się najodpowiedniejszy. Marescotti zaapelował ponad to o udzielenie mu wszelkich honorów i precedencji, którymi cieszyli się w podobnych sytuacjach politycznych jego poprzednicy na urzędzie, zważywszy na autorytet Stolicy Apostolskiej, który reprezentował.

Prymas oraz marszałkowie zgodnie odpowiedzieli, że instancja Marescottiego przedstawiona zostać będzie musiała na sejmie, a następnie decyzja, co do udzielenia mu audiencji, przekazana zostanie bezzwłocznie do wiadomości samego zainteresowanego. Sprawa ta została poruszona w dyskusji sejmowej dopiero w piątek 31 maja, w wystąpieniu podkomorzego łęczyckiego Stefana Sarnowskiego ${ }^{32}$. Zaproponowano wówczas udzielenie nuncjuszowi audiencji nazajutrz, w sobotę 1 czerwca. Nie powzięto jednak żadnych konkretnych rezolucji w tej sprawie, ze względu na to, że część szlachty upierała się nad koniecznością kontynuacji prac na egzorbitancjami i nad ich priorytetowością względem audiencji, których miano udzielić ambasadorom zagranicznym ${ }^{33}$.

Sprawa posłuchania nuncjusza powróciła na obrady nazajutrz, w dniu 1 czerwca, kiedy to marszałek sejmu Potocki zaproponował, aby „oznajmiono było księdzu nuncjuszowi Ojca Świętego, że będzie dziś miał audiencję" 34 . Spośród wszystkich posłów zagranicznych do posłuchania dopuszczony miał zostać jedynie reprezentant Stolicy Apostolskiej, jako przybywający na elekcję cum benedictione, „ex quo veneratio sacrae, sed debetur, żeby nie przetrzymywać posła tego na rzeczy, do tego, że żadnego kandydata nie promowuje, [...] ale żeby hoc exemplo nie pretendowali insi audiencji" ${ }^{35}$. Wszystkie inne posłuchania miały pozostać

32 BC, rkps 1661, k. 35r, Diariusz sejmu elekcyjnego 1669 r.

33 AAV, Segr. di Stato, Polonia 83, k. 196r, Avviso di Varsavia, 5 VI 1669. Por. Vademecum pro nuntiis apostolicis in Polonia a Galeazzo Marescotti, Nuntio Apostolico, circa a. 1670 exaratum, quod apud Ciampi inscribitur L'istruzione al nuovo Nunzio di Polonia, wyd. A. Kakowski, Petropoli 1912, s. 69. AAV, Segr. di Stato, Polonia 83, k. 152r, Avviso di Varsavia, 29 V 1669; BC, rkps 408, k. 94r, Diariusz Elekcji Króla Jegomości Michała. Anno Domini 1669 odprawionej; BC, rkps 408, k. 570v, Diariusz Elekcji Króla Michała. Protestował wówczas przede wszystkim podkomorzy kaliski Stanisław Krzycki. Zob. BK, rkps 316, k. 316r, Diariusz sejmu electionis 1669.

34 J.A. Chrapowicki, Diariusz. Cz. 2, Lata 1665-1669, oprac. A. Rachuba, T. Wasilewski, Warszawa 1988, s. 497. Por. BC, rkps 408, k. 570v, Diariusz Elekcji Króla Michała: „Zasiadszy w kole po południu Pan Marszałek Koła Rycerskiego powinszował naprzód dziś zaczętych egzorbitancji, żałował przytym barzo, iż dnia wczorajszego przy solwowaniu Sesji proponowawszy audiencję posła od Ojca Świętego y nie słysząc kontradykcji temu, zaraz wczoraj obdestinavit Jego Mości Księdza Nuncjusza o audiencji, a dziś usłyszą o kontradykcji, jakoby zgody na to nie było. Życzy tedy tę materię wziąć przed się".

35 BK, rkps 316, k. 316r, Diariusz sejmu electionis 1669. 
odłożone w czasie i odbyć się po zakończonych egzorbitancjach ${ }^{36}$. Nieprzychylni projektowi wysłuchania nuncjusza jeszcze tego samego dnia, po południu, okazali się jednak prymas Prażmowski wraz z Wielkopolanami, oraz Sandomierzanie, stale i bezwzględnie naciskający na konieczność wcześniejszego omówienia egzorbitancji. Chorąży sandomierski Stanisław Witowski zaapelował ponadto, żeby decyzję o przyjmowaniu audiencji posłów zagranicznych i o ich czasie podjęli między sobą prymas wraz z marszałkami, następnie przedstawiając konkretny już projekt szlachcie. Demonstrował on ostrożność polityczną wobec osoby nuncjusza, gdyż, jak zanotował autor jednego z diariuszy sejmowych: „Mogła by dana bydź audiencja Jego Mości Księdzu Nuncjuszowi, ale iż słychać jakoby kogo wprowadzać miał za kandydata, dlatego żadnej nie może bydź audiencji" ${ }^{37}$. Nie brakowało jednak i głosów przychylnych wysłuchaniu papieskiego dyplomaty, szczególnie pośród Mazowszan, albo tak jak ten przedstawiony przez sędziego sanockiego: „Posłom cudzoziemskim, którzy tylko cum ceremonia, testificatione affectus boni przychodza, nie z konkurencja, audiencję pozwolić, jako Jego Mości Księdzu Nuncjuszowi cum benedictione od Ojca Świętego przychodzącemu; życzy1"38. Również sam marszałek sejmu Potocki dalej forsował jak najszybsze udzielenie audiencji przybywającemu cum benedictione Marescottiemu, „,gdyż insze choć pogańskie narody zawsze venerantur posłów od Ojca Świętego, daleko większe poszanowanie bydź powinno od tych, którzy zażywają łaski" 39 . Jego słowa spotkać się miały z ogólną aprobatą zgromadzenia, niemniej jednak o audiencji wciąż nic konkretnego nie postanowiono. Tego samego dnia pojawiły się natomiast liczne głosy dążących do jak najszybszej ekskluzji poszczególnych kandydatur: Ludwika II Burbona de Condé, Filipa Wilhelma Neuburga i Karola V Lotaryńskiego ${ }^{40}$.

Kwestia posłuchań ambasadorów zagranicznych długo pozostawała zatem na drugim planie obrad. Żadne wiadomości nie napływały $w$ tej sprawie do nuncjusza, aż do poniedziałkowego wieczoru 3 czerwca, kiedy to dotarły do niego wieści o dyskusji, jaka poruszyła tego dnia obradami sejmu. Po raz kolejny dotyczyła ona egzorbitancji i czy debata nad nimi

36 J.A. Chrapowicki, op. cit., s. 497; BO, rkps 239/III, k. 40v-41, Diariusz sejmu elekcyjnego; BC, rkps 404, k. 85, Diariusz Sejmu Elekcji.

37 BC, rkps 408, k. 571r, Diariusz Elekcji Króla Michała. Por. F. Hirsch, Zur Geschichte der polnischen Königswahl von 1669. Danziger Gesandtschaftsberichte aus den Jahren 1668 und 1669, "Zeitschrift des Westpreußischen Geschichtsvereins” 1889, 25, s. 61; BC, rkps 164, k. 199, Diariusz Wolnej Elekcji.

38 BC, rkps 408, k. 571r, Diariusz Elekcji Króla Michała. Por. F. Hirsch, op. cit., s. 61.

39 Ibidem, k. $571 \mathrm{v}$.

40 F. Hirsch, op. cit., s. 61; J.A. Chrapowicki, op. cit., s. 497; BC, rkps 404, k. 85, Diariusz Sejmu Elekcji; BC, rkps 408, k. 94r, Diariusz Elekcji Króla Jegomości Michała. 
powinna się zakończyć przed zaproszeniem do audiencji ambasadorów zagranicznych. Marescottiego szczególnie poruszyło wówczas postawienie go na równi z pozostałymi dyplomatami przybyłymi na elekcję; uważał on bowiem, że: „nuncjusz apostolski nie może być traktowany na równi z innymi ambasadorami, mając na względzie osobę, którą reprezentuje, o charakterze nadrzędnym w stosunku do innych [książąt]. Powinien być on zatem bezwzględnie jak najszybciej wysłuchanym, a dopiero w drugiej kolejności można rozważyć to, co dotyczy posłuchań ministrów innych książąt" ${ }^{\prime 1}$.

Ostatecznie w dniu 3 czerwca, podczas popołudniowej sesji obrad sejmu elekcyjnego, zdecydowano jednak o priorytetowym wysłuchaniu nuncjusza, z zastrzeżeniem: „tylko samemu ex quo cum benedictione przychodzi, inszych zaś ablegatos visum est zachować post exorbitantiar, co sobie vel maxime Wielgopolanie i Sandomierzanie provocabant" ${ }^{\prime \prime 2}$. Co ciekawe, decyzja ta zapadła w dniu absencji marszałka poselskiego Potockiego, którego zastąpił wówczas starosta spiski Stanisław Herakliusz Lubomirski ${ }^{43}$. I tym razem wciąż nie brakowało jednak głosów sceptycznie nastawionych do udzielenia audiencji nuncjuszowi, które wyraził np. podkomorzy kaliski Stanisław Krzycki („,co do audiencji Jego Mości Księdza Nuncjusza, dlatego ta materia długo in deliberatione versatur, bo egzorbitancje oporem ida, a dawszy jednemu posłowi audiencji wszyscy by chcieli" ${ }^{44}$ ). Głosy sprzyjające wysłuchaniu papieskiego dyplomaty wyrazili wówczas natomiast sędzia chełmski Zbigniew Sługocki, starosta oświęcimski Jan Pieniążek, marszałek rzeczycki Leon Jan Pogirski, sędzia wileński Tobiasz Pękalski oraz starosta krośnieński Karol Fredro, większość z zastrzeżeniem, aby nie stanowiło ono precedensu, który wykorzystaliby następnie pozostali ambasadorowie zagraniczni przebywający w Warszawie ${ }^{45}$. Ostatecznie to bez wattpienia specyfika reprezentowanego

41 Vademecum, s. 69. Por. AAV, Arch. Nunz. di Varsavia 174, k. 103r, Breve relatione dell'Udienza publica: „Il Nontio Apostolico non deve essere considerato del pari con gl'altri Ambasciatori, portando per la persona, che rappresenta carattere superiore agl'altri, onde dover esser udito in ogni maniera con sollecitudine, potendosi poi rifletter à ciò, che fusse espediente in ordine al sentire li Ministri degl'altri Principi".

42 BC, rkps 404, k. 87, Diariusz Sejmu Elekcji. Por. M. Chmielewska, Sejm elekcyjny Michała Korybuta Wiśniowieckiego 1669 roku, Warszawa 2006, s. 203; F. Hirsch, op. cit., s. 62; J.A. Chrapowicki, op. cit., s. 498; BO, rkps 3564, k. 438v, Actus Electionis Anno Domini Millesimo Sexcentesimo Sexagesimo Nono, Secunda Maii w Wigilią Świętego Krzyża. Post Abdicationem Jana Kazimierza Króla za Dyrekcyi Jegomości Pana Potockiego Podstolego Koronnego; BC, rkps 164, k. 200-201, Diariusz Wolnej Elekcji; BC, rkps 408, k. 94r, Diariusz Elekcji Króla Jegomości Michała; BK, rkps 316, k. 316r, Diariusz sejmu electionis 1669.

${ }_{43}$ BC, rkps 408, k. 571v, Diariusz Elekcji Króla Michała.

44 Ibidem.

45 Ibidem, k. 572r; BK, rkps 365, k. 14r, Connotatio transactionum. 
przez nuncjusza autorytetu padre comune zadecydowała w końcu o przesunięciu audiencji reprezentanta Stolicy Apostolskiej na liście sejmowych priorytetów. Jak zauważył cytowany już powyżej włoski historyk Andretta: „,zakładając subtelność i obsesję na punkcie aspektów ceremonialnych, od nuncjuszy oczekiwano szczególnego zaangażowania dla zachowania cnotliwej i życzliwej postawy, tak w mądrości, jak i w godności, jako od reprezentantów największego monarchy Wszechświata, Namiestnika Chrystusa na ziemi, Ojca i Pasterza wszystkich wiernych. Zwrócone są na nich oczy maluczkich i wielkich, obserwujące to, co mówią, i zauważające to, co robią"46.

Audiencję Marescottiego zaplanowano w trybie natychmiastowym, bo już nazajutrz, we wtorek 4 czerwca, o godzinie 14. Było to zresztą utartym zwyczajem w polsko-litewskiej praktyce dyplomatycznej, aby o terminie audiencji decydować dzień wcześniej, lub nawet o poranku tego samego dnia, jeśli miała się ona odbyć w późnych godzinach popołudniowych.

\section{AUDIENCJA PUBLICZNA NUNCJUSZA GALEAZZA MARESCOTTIEGO NA SEJMIE ELEKCYJNYM 1669 R.}

W dniu audiencji, 4 czerwca 1669 r., około wyznaczonej godziny 14, pod kwatery nuncjusza (mieszczące się $\mathrm{w}$ warszawskim Lesznie ${ }^{47}$ ) przyjechał orszak powozów, na czele z karetą Prażmowskiego, eskortowaną przez dragonów i hajduków należących do gwardii prymasa. Zasiadali

46 S. Andretta, op. cit., s. 201. Fragm. cyt. G. Bragaccia, L'ambasciatore, Padova 1627, s. 596: "Con un'implicita ammissione della delicatezza e dell'ossessività degli aspetti cerimoniali, dai nunzi si pretendeva una maggiore attenzione nei comportamenti virtuosi e nella pietà, nella saggezza come nella dignità come rappresentanti il maggior monarca dell'Universo, il Vicario di Cristo in terra, il Padre e Pastore di tutti i fedeli, girano gli occhi piccioli e grandi et osservano ciò che dicono et notano ciò che fanno".

47 Jurydyka Leszno założona została w 1648 r.przez podskarbiego wielkiego koronnego Bogusława Leszczyńskiego i kanclerza wielkiego koronnego Jana Leszczyńskiego. Zob. K. Handke, Dzieje Warszawy nazwami pisane, Warszawa 2011, s. 160. Mieczysława Chmielewska podała, że trasa przejazdu nuncjusza wiodła z Leszna na miejsce elekcji, nie wyjaśniła jednak lokalizacji Leszna jako jednej z ówczesnych dzielnic Warszawy. Por. M. Chmielewska, op. cit., s. 203-204. Marescotti określił swoją rezydencję słowami "casa della decania", i chodzi zapewne o zabudowania należące do klasztoru Bonifratrów. Zob. Vademecum, s. 33. Ciekawe badania nad rezydencjami nuncjuszy apostolskich przeprowadził Tadeusz Fitych, nie obejmują one jednak badanego okresu. Zob. Personel i organizacja nuncjatury Giovanniego Battisty Lancellottiego 31-szego posła apostolskiego w Polsce (1622-1627), „Saeculum Christianum: pismo historyczno-społeczne” 2001, 8, 1, s. 67-71; Struktura i funkcjonowanie nuncjatury Giovanniego Battisty Lancellottiego (1622-1627), Opole 2005, s. 296-307. 
w niej biskupi reprezentujący hierarchię kościelną Korony i Litwy: łucki Tomasz Leżeński i żmudzki Kazimierz Pac, a także referendarz koronny Jan Małachowski (zastępujący niedawno zmarłego sekretarza wielkiego koronnego Andrzeja Miaskowskiego, który według obowiązującego ceremoniału powinien był być obecny przy powitaniu dyplomaty Stolicy Apostolskiej). Delegacja ta oficjalnie pozdrowiła nuncjusza w jego rezydencji ${ }^{48}$ (choć według jednego z diariuszy "dla ścisku inszych karoc które tam już czekały wjachać się nie mogły, zszedł Jego Mość Ksiądz Nuncjusz na dó' $\left.{ }^{\prime 49}\right)$. W jednym $\mathrm{z}$ włoskich awiz znamiennie nazwano owych dostojników Ambasadorami Rzeczypospolitej (Ambasciatori della Republica) ${ }^{50}$.

Tuż za karetą prymasa pod rezydencję Marescottiego podjechało około 70 sześciokonnych powozów (nuncjusz w swojej relacji podaje dokładną liczbę $64^{51}$, autor jednego z diariuszów pisze nawet o 90 karetach $^{52}$ ), w których zasiadali duchowni, szlachta, a także ambasadorowie cesarski Krzysztof Leopold Schaffgotsch i francuski Pierre de Bonzi wraz z własnymi orszakami ${ }^{53}$. Za nimi podążały mniejsze, dwukonne powozy. Wierzchem zjechała się również liczna szlachta (według relacji nuncjusza jeźdźców było około $400^{54}$, diariusze sejmu elekcyjnego przytaczają liczbę 500 konnych ${ }^{55}$ ). To właśnie marsz owej jazdy otwierał cały poczet powozów.

W dniu swej audiencji publicznej na sejmie elekcyjnym 1669 r., Marescotti został zaproszony do przysłanej przez prymasa karety, w której usiadł przodem do kierunku jazdy, mając naprzeciw wyżej wymienionych biskupów Leżeńskiego i Paca, a po bokach Małachowskiego oraz unickiego metropolitę kijowskiego Gabriela Kolendę, któremu szczególnie zależeć miało na udzieleniu reprezentantowi Stolicy Apostolskiej ho-

48 Vademecum, s. 69; AAV, Arch. Nunz. di Varsavia 174, k. 103v, Breve relatione dell'Udienza publica. Zob. też AAV, Segr. di Stato, Polonia 83, k. 178v, Avviso di Varsovia, 5 VI 1669.

49 BK, rkps 316, k. 316v, Diariusz sejmu electionis 1669.

50 AAV, Segr. di Stato, Avvisi 115, k. 111v, Avviso di Varsovia, 4 VI 1669.

51 Vademecum, s. 69; AAV, Arch. Nunz. di Varsavia 174, k. 103v, Breve relatione dell'Udienza publica. Zob. też AAV, Segr. di Stato, Polonia 83, k. 178v, Avviso di Varsovia, 5 VI 1669. s. 204 .

52 BK, rkps 316, k. 316v, Diariusz sejmu electionis 1669. Por. M. Chmielewska, op. cit.,

53 Zob. Vademecum, s. 69; AAV, Arch. Nunz. di Varsavia 174, k. 103r, Breve relatione dell'Udienza publica; AAV, Segr. di Stato, Polonia 83, k. 178v, Avviso da Varsavia, 5 VI 1669.

54 Vademecum, s. 69; AAV, Arch. Nunz. di Varsavia 174, k. 103v, Breve relatione dell'Udienza publica; AAV, Segr. di Stato, Polonia 83, k. 178v, Avviso da Varsavia, 5 VI 1669.

55 BO, rkps 239/III, k. 42r, Diariusz sejmu elekcyjnego; BK, rkps 1368, k. 115v, Diariusz wolnej elekcji po abdykacji Jana Kazimierza; BC, rkps 164, k. 204, Diariusz Wolnej Elekcji; BC, rkps 404, k. 90, Diariusz Sejmu Elekcji. 
norów i osobistej asysty ${ }^{56}$. Przed karetą prymasowska, w której zasiadł nuncjusz, jechał powóz marszałka wielkiego koronnego Sobieskiego, w którym zasiedli ambasadorowie zagraniczni: zapewne reprezentanci cesarstwa i Francji ${ }^{57}$. Bezpośrednio za karetą prymasa podążały natomiast 3 lub 4 sześciokonne powozy należące do reprezentanta Stolicy Apostolskiej, w których jechali członkowie jego familii dyplomatycznej ${ }^{58}$, powozy należące do orszaków posłów zagranicznych Schaffgotscha i De Bonziego, a następnie poczet karet senatorskich i znamienitszej szlachty. Autor jednego z diariuszy napisał, iż „niemal każdy z tychże wielkich Panów posłał karetę, i kawalkatę swoją jak należy przybraną czyniąc honor posłowi albo w osobie jego Ojcu Świętemu" ${ }^{\prime 2}$.

Cała droga w kierunku pola elekcyjnego obstawiona była gwardiami, zarówno pieszymi, jak i konnymi, najbardziej prominentnych senatorów, którzy chcieli $\mathrm{w}$ ten sposób oddać honory reprezentantowi Stolicy Apostolskiej, a przede wszystkim zapewne podkreślić własną pozycję i prestiż. Nuncjusz oceniał ich liczebność na 7 tys. ludzi ${ }^{60}$, niektóre awiza podają natomiast wiadomości o $8-{ }^{61}$ lub 10 tys. ${ }^{62}$ orszaku, podczas gdy autor jednego z diariuszy ocenił liczbę asystujących przejazdowi papieskiego dyplomaty i chcących osobiście pozdrowić reprezentanta Klemensa IX nawet na kilkanaście tys. osób ${ }^{63}$. Informacje te potwierdza diariusz Jana Antoniego Chrapowickiego, wg którego „stały piechoty liczne, konnych wielkie gromady, ba, jak całe pułki" ${ }^{64}$. Nuncjusza pozdrawiano wymachując proporcami i oddając salwy z broni palnej ${ }^{65}$. „Prowadzili go różni panowie senatorowie i kawalkaty strojne" 66 - relacjonował dalej Chrapo-

56 Vademecum, s. 69; AAV, Arch. Nunz. di Varsavia 174, k. 103v, Breve relatione dell'Udienza publica; AAV, Segr. di Stato, Polonia 83, k. 178v, Avviso da Varsavia, 5 VI 1669.

57 BC, rkps 408, k. 94v, Diariusz Elekcji Króla Jegomości Michała: „Jako i w innych wszytkich niemal politycznych Państwach tak się zachowuje, że immediate chodzić zwykła karoca marszałkowska przed królewska, przeto kiedy się trafią extraneorum Principum aliqui Legati z swoich karoc wysiadają a do marszałkowskiej wsiadaja, swoją przed tą puściwszy". Por. BC, rkps 408, k. 573r, Diariusz Elekcji Króla Michała.

58 BK, rkps 316, k. 316v, Diariusz sejmu electionis 1669.

59 BC, rkps 408, k. 94v, Diariusz Elekcji Króla Jegomości Michała.

60 Vademecum, s. 70; AAV, Arch. Nunz. di Varsavia 174, k. 104r, Breve relatione dell'Udienza publica; AAV, Segr. di Stato, Polonia 83, k. 179r, Avviso da Varsavia, 5 VI 1669.

${ }^{61}$ BC, rkps 164, k. 204, Diariusz Wolnej Elekcji; BC, rkps 404, k. 90, Diariusz Sejmu Elekcji.

62 AAV, Segr. di Stato, Avvisi 115, k. 111v, Avviso di Varsovia, 4 VI 1669; Biblioteca Apostolica Vaticana [dalej: BAV], Barb. lat. 6371, k. 206r, Avvisi 1668-1669, Varsavia, 4 VI 1669.

63 BC, rkps 408, k. 94, Diariusz Elekcji Króla Jegomości Michała.

64 J.A. Chrapowicki, op. cit., s. 498.

65 BAV, Barb. lat. 6371, k. 206r, Avvisi 1668-1669, Varsavia, 4 VI 1669.

66 J.A. Chrapowicki, op. cit., s. 499. 
wicki. „Legata Ojca Świętego wprowadzały do okopu wszystkich Panów gwardie, których było przednie pięknych i strojnych numero osiemdziesiąt choraggwi" ${ }^{67}$ - podał natomiast autor innej z sejmowych relacji. Senatorowie wysłali nuncjuszowi naprzeciw kawalerię i piechotę: husarię, rajtarię, dragonię, z chorągwiami kozackimi, tatarskimi, węgierskimi, a także Semenów i Multanów. Chorągwie te rozstawione były gęsto po obu stronach drogi prowadzącej z warszawskiego Leszna w kierunku pola elekcyjnego na Woli. Pochodowi towarzyszyła ponadto muzyka wojskowa: dźwięki bębnów, kotłów, trąb, surm i piszczałek.

Po opuszczeniu Warszawy, na znak wystrzału z muszkietu, pochód zatrzymał się przy klasztorze franciszkańskim, znajdującym się na południe od miasta, przy Bramie Krakowskiej. Nuncjusza powitali tam marszałek i hetman wielki koronny Sobieski oraz książę Michał Wiśniowiecki (jako reprezentanci Korony i Litwy $)^{68}$. Marescotti wysiadł wtedy z karety, stojąc wysłuchał ich pozdrowienia i uprzejmie odpowiedział po łacinie ${ }^{69}$. Jak się wówczas okazało, i oni powinni byli wcześniej dotrzeć do warszawskiej rezydencji nuncjusza, spóźnieni jednak, konno, ale smontati a piedi, zatrzymali orszak papieskiego dyplomaty już poza murami miasta, a następnie włączyli się do pochodu, wsiadając do przygotowanej dla nich karocy podążającej za powozem ambasadora cesarskiego, przed innymi powozami senatorskimi ${ }^{70}$.

Tymczasem, od około godziny 14, uczestnicy obrad sejmu zaczęli się pojawiać na polu elekcyjnym. Senatorowie już wcześniej wjechali do szopy, a następnie przenieśli się na czas powitania papieskiego reprezentanta do koła i tam wspólnie ze zgromadzoną szlachtą własnego województwa bądź ziemi (senatorowie świeccy) oczekiwali na przyjazd nuncjusza Klemensa IX. Hierarchowie duchowni, a wraz z nimi najwyżsi koronni i litewscy urzędnicy dworscy, zajęli natomiast centralne miejsca pomiędzy województwami krakowskim a poznańskim ${ }^{71}$. Co ciekawe, autor jednego z diariuszy zauważył, że tego rodzaju połączenie izb z okazji audiencji

67 BO, rkps 3564, k. 438v-439r, Actus Electionis.

68 Opisanie elekcyi króla Michała Korybuta Wiśniowieckiego, z pisemka drukowanego w Rzymie roku 1669, przypisanego kardynałowi Orsini protektorowi Polski przez Jana Baptyste Gisleni, w: Relacye nuncyuszów apostolskich $i$ innych osób o Polsce od roku 1548 do 1690, t. 2, wyd. E. Rykaczewski, Berlin-Poznań 1864, s. 356; Vademecum, s. 70; AAV, Arch. Nunz. di Varsavia 174, k. 104r, Breve relatione dell'Udienza publica; AAV, Segr. di Stato, Polonia 83, k. 179r, Avviso da Varsavia, 5 VI 1669.

69 Vademecum, s. 70; AAV, Arch. Nunz. di Varsavia 174, k. 104r, Breve relatione dell’Udienza publica; AAV, Segr. di Stato, Polonia 83, k. 179r, Avviso da Varsavia, 5 VI 1669.

70 Ibidem.

71 BC, rkps 408, k. 94v, Diariusz Elekcji Króla Jegomości Michała; BC, rkps 408, k. 572v-573r, Diariusz Elekcji Króla Michała. 
nuncjusza apostolskiego było bezprecedensowe i contra usum et consuetudinem antiquam. Podczas poprzednich dwóch elekcji (1632 i 1648) senatorowie nie przychodzili do koła, a jedynie opuszczali ciasną szopę, by w klasycznym dla senatu porządku usiąść w następującym szyku: „,Biskupi tyłem do szopy, a świetcy Senatorowie ut moris est po obu bokach"72. Wokół gromadziła się wówczas szlachta i w ten sposób przyjmowano legacje posłów zagranicznych ${ }^{73}$. Jeszcze wcześniej, w XVI w., wszystkie posłuchania posłów zagranicznych odbywały się w szopie senatorskiej. Odwoływano się wówczas do zasady reprezentacji województw ze względu na brak miejsca dla szlachty. Obecni byli natomiast wszyscy senatorowie. Po każdej oracji teksty przemówień przekazywane były reprezentantom poszczególnych ziem, w których to zgromadzeniach dokonywano kolejnych odczytów tak, aby każdy obecny na elekcji szlachcic mógł zapoznać się z ich treścią ${ }^{74}$. Autor wspomnianego wyżej diariusza podkreślił, że podczas elekcji 1669 r. było „inaczej, bo i Senat contra suam autoritatem do młodszej Braci przyszli i nie swoim porządkiem lecz sparsim zasiedli skąd nulla Maiestas, et minor Ordo, że nie we śrzodku i nie porządkiem miejsca pobrali, aleć takowe novitates z czasami się rodzą utinam bono omine $^{\prime \prime 75}$. Kolejną ciekawą adnotacją jednego z autorów diariuszy jest fakt fizycznego przeniesienia krzeseł senatorskich z szopy do koła: „wszedłszy w koło rycerskie, eo Ordine jako w szopie tak też w porządku koła rycerskiego na krzesłach swych zasiedli"76, podkreślając tym samym swą senatorską godność w gronie zgromadzonej szlachty.

Na Woli, we wschodniej bramie pola elekcyjnego, nuncjusza Stolicy Apostolskiej Marescottiego powitali biskupi warmiński Jan Stefan Wydżga i kijowski Tomasz Ujejski ${ }^{77}$, wojewodowie mazowiecki Wojciech Krasiński i lubelski Władysław Rey, kasztelanowie wołyński Stanisław Kazimierz Bieniewski i brzeskolitewski Stefan Kurcz, „,którzy przeciwko posłowi z okopu na piętnaście kroków circiter wyszedłszy przy samej ka-

72 BC, rkps 408, k. 573r, Diariusz Elekcji Króla Michała.

73 Ibidem.

74 P. Skwarczyński, Pierwsze trzy wolne elekcje "viritim" 1573-1587, „Teki Historyczne” 1959, 10, s. 119-154; D. Gregorowicz, The Role of Papal Diplomats in the Interregnum's Parliamentary Practice of the Polish-Lithuanian Commonwealth (16th-17th centuries), „Dimensioni e problemi della ricerca storica” 2016, 29, 1, s. 128; eadem, Tiara w grze o korone. Stolica Apostolska wobec wolnych elekcji w Rzeczypospolitej Obojga Narodów w drugiej połowie XVI wieku, Kraków 2019, s. 248.

75 BC, rkps 408, k. 573r, Diariusz Elekcji Króla Michała.

76 BK, rkps 365, k. 14r, Connotatio transactionum. Zob. też BC, rkps 1661, k. 40, Diariusz sejmu elekcyjnego $1669 \mathrm{r}$.

77 Chmielewska błędnie podaje jako ówczesnego biskupa kijowskiego Wespazjana Lanckorońskiego. Por. M. Chmielewska, op. cit., s. 204. 
rocy go przyjęli"78, odprowadzając następnie do koła. Przy samym okopie Marescotti powitany został przez dwóch obecnych na sejmie marszałków: wielkiego koronnego Sobieskiego oraz sejmu elekcyjnego Potockiego, a także kanclerza wielkiego litewskiego Krzysztofa Zygmunta Paca ${ }^{79}$. Przy wkroczeniu dyplomaty papieskiego do koła wszyscy zgromadzeni wstali, okazując mu szacunek, niektórzy nawet (,wszyscy Biskupi, i prawie wszyscy Senatorzy" ${ }^{\prime 80}$ ) ruszyli kilka kroków w przód, w stronę nuncjusza.

Dotarłszy do serca pola elekcyjnego około godziny $18^{81}$, reprezentant Stolicy Apostolskiej został następnie oficjalnie powitany przez prymasa Prażmowskiego, który wyszedł mu naprzeciw do połowy koła ${ }^{82}$, a następnie, na zaproszenie tego ostatniego, Marescotti przyjął najdostojniejsze możliwe miejsce: na czele całego episkopatu, zajmując krzesło (una sedia più pomposa dell'altre ${ }^{83}$ ) pomiędzy arcybiskupem gnieźnieńskim (po prawej), a biskupem krakowskim Trzebickim (po lewej stronie). Tym samym spełniony został postulat Sekretariatu Stanu Stolicy Apostolskiej, dotyczący zachowania ceremonialnej precedencji swojego przedstawiciela, o który tak bardzo się w Rzymie obawiano. Arcybiskup lwowski Tarnowski, tak jak to już od wielu miesięcy przewidywano, był nieobecny na elekcji ze względu na podeszły wiek i zły stan zdrowia. Co ciekawe w kontekście opisanych powyżej chłodnych stosunków i rywalizacji Marescottiego z Prażmowskim, niektóre z diariuszy sejmowych mówią o ustapieniu przez prymasa własnego miejsca nuncjuszowi ${ }^{84}$.

Kiedy po ceremonii powitania reprezentanta Stolicy Apostolskiej wszyscy ponownie usiedli, nuncjusz przekazał na ręce prymasa dwa papieskie brewia: pierwsze zaadresowane do senatorów Rzeczypospolitej (Dilectis filiis Nobilibus Viris Ordini Senatorio Regni Poloniae, et Magni Ducatus Lithuaniae), drugie do zgromadzonej szlachty (Dilectis filiis Universo Ordini Equestri Regni Poloniae, et Magni Ducatus Lithuaniae). Nuncjusz przypilnował, aby do intytulacji dołączone zostało Wielkie Księstwo Litewskie, które w początkowo przygotowanej przez kancelarię papieską wersji brewiów zostało nieopatrznie pominięte, co mogłoby na polu elekcyjnym spowodować niemałą obrazę (uwagę na to zwrócili wcześniej Marescottiemu

\footnotetext{
78 BK, rkps 316, k. 316v, Diariusz sejmu electionis 1669.

79 Ibidem. Zob. też M. Chmielewska, op. cit., s. 204.

80 AAV, Segr. di Stato, Polonia 83, k. 179r, Avviso da Varsavia, 5 VI 1669: „Tutti i Vescovi, e quasi tutti li Senatori".

81 BC, rkps 1661, k. 40, Diariusz sejmu elekcyjnego 1669 r.

82 BK, rkps 316, k. 316v, Diariusz sejmu electionis 1669.

83 Vademecum, s. 70; AAV, Arch. Nunz. di Varsavia 174, k. 104r, Breve relatione dell'Udienza publica; AAV, Segr. di Stato, Polonia 83, k. 179r, Avviso da Varsavia, 5 VI 1669.

84 BK, rkps 1368, k. 115v, Diariusz wolnej elekcji; BC, rkps 164, k. 204, Diariusz Wolnej Elekcji; BC, rkps 404, k. 90, Diariusz Sejmu Elekcji.
} 
prymas Prażmowski i biskup krakowski Trzebicki) ${ }^{85}$. Atencja papieskiego dyplomaty pozostała nie bez echa, jako że i autorzy diariuszy sejmu elekcyjnego podkreślali, iż papieskie brewia były napisane „dość pięknie et cum debitis titulis" 86 .

Listy papieskie odpieczętował i otworzył prymas, a odczytane zostały one następnie na głos pośrodku koła przez referendarza koronnego Małachowskiego ${ }^{87}$ (brewe skierowane do senatorów) oraz przez marszałka sejmu Potockiego (brewe skierowane do szlachty, tu ciekawa adnotacja w diariuszu Chrapowickiego dotycząca problemów marszałka z rozczytaniem włoskiego duktu pisma brewe $\left.{ }^{88}\right)$.

Po prezentacji listów papieskich nuncjusz, zgodnie z obowiązującą praktyka, wygłosił mowę okolicznościową. Oracja była rozwiązaniem retorycznym szczególnie charakterystycznym dla epoki baroku. Mówca budował za jej pośrednictwem więź ze słuchaczami, przeżywającymi emocjonalnie jego przekaz. Niestety pozajęzykowe metody ekspresji związane $\mathrm{z}$ wygłaszaniem oracji nie zachowały się na piśmie i bardzo trudno je odtworzyć na podstawie poszlakowych przesłanek. Mowa tu na przykład o modulacji głosu oratora, jego wyglądzie zewnętrznym oraz postawie przyjmowanej na czas przemówienia. Dzięki szczegółowej relacji Marescottiego wiemy, iż przywdziewał on w tym dniu długą sutannę o kolorze rubinowym (biskupim), rokietę, mantolet, mucet, biret w kolorze sutanny, a także złoty, zdobiony szlachetnymi kamieniami krzyż pektoralny ${ }^{89}$. Były to zatem charakterystyczne elementy tzw. stroju chórowego, czyli ubioru duchownych noszonego podczas liturgii, w czasie gdy jej nie sprawują a są jedynie jej uczestnikami ${ }^{90}$. Należy zaznaczyć, że do właściwej części swojego wystąpienia (przede wszystkim podczas rytuału powitania oraz przekazania i odczytania listów papieskich) nuncjusz ściągał nakrycie głowy, podobnie czynili również wszyscy zgromadzeni $^{91}$. W swojej elekcyjnej oracji Marescotti przekazywał zgromadzonej

85 Vademecum, s. 70-71; AAV, Arch. Nunz. di Varsavia 174, k. 104v, Breve relatione dell'Udienza publica; AAV, Segr. di Stato, Polonia 83, k. 179v, Avviso da Varsavia, 5 VI 1669.

86 BC, rkps 408, k. 573v, Diariusz Elekcji Króla Michała.

87 Jeden z diariuszy błędnie podaje, iż lektorem był kanonik warszawski, ksiądz Szczuka. Zob. BO, rkps 3564, k. 439r, Actus Electionis. Odczytujący brewe Małachowski zastępował sekretarza wielkiego koronnego, który to urząd od 1668 r. wakował. Zob. BC, rkps 408, k. 94v, Diariusz Elekcji Króla Jegomości Michała; BC, rkps 408, k. 573v, Diariusz Elekcji Króla Michała.

88 J.A. Chrapowicki, op. cit., s. 499.

89 Vademecum, s. 17.

90 Ibidem, s. 16, 69; AAV, Arch. Nunz. di Varsavia 174, k. 103r, Breve relatione dell'Udienza publica.

91 Vademecum, s. 18. 
szlachcie papieskie błogosławieństwo, apelując o zgodną elekcję monarchy, a także o zachowanie pokoju wewnętrznego w Rzeczypospolitej (nihil in praesens conducibilius, nihil consultius est, quam unanimis cunctorum Ordinum in optimo Rege eligendo concordia), przywołując wstawiennictwo Ducha Świętego. Naciskał oczywiście na wyznanie przyszłego monarchy, który musiał być katolikiem, ostrzegając przede wszystkim przed niebezpieczeństwem Orthodoxae Religionis, czyli oczywiście przed kandydaturą carewicza. Powtarzającą się w oracji Marescottiego była kwestia konieczności kontynuacji walki pomiędzy Reipublica Christiana a Imperium Osmańskim. Nuncjusz wskazywał kluczowość elekcji w Rzeczypospolitej $\mathrm{w}$ tej perspektywie (choć w miesiącach poprzedzających polsko-litewską elekcję Stolica Apostolska była w rzeczywistości daleko bardziej zainteresowana np. wydarzeniami wojny kandyjskiej). Reprezentant Klemensa IX nie wskazywał żadnego faworyzowanego przez Stolicę Apostolską kandydata do korony, zajmując $w$ tym zakresie tradycyjne stanowisko neutralnego padre comune $e^{92}$. Marescotti, idąc za przykładem jednego ze swych poprzedników De Torresa, przydawał Rzeczypospolitej tytuł Serenissima, a także konsekwentnie używał retoryki ukierunkowanej na pozyskanie sobie szlacheckich łask, używając wyrażeń takich jak: Sarmatico Imperio; [...] Domus Dei in hac septentrionali plaga fulcitur colossum, cuius strenuos Incolas in Catholici Orbis finibus Divina Providentia collocavit; [...] Sarmaticam enim gentem Catholicae Religioni deditissimam in his, quae ad divini obsequium numinis, decorem Domus Dei, atque Sanctae fidei studium pertinent, nulla ex Septentrionalibus Nationibus antecellit ${ }^{93}$; etc. Tego typu nawiązania do wysokiej pozycji społecznej warstwy uprzywilejowanej, eksponujące szlacheckie wartości, jako niezwykle sugestywne komunikacyjnie określił niedawno Filip Wolański ${ }^{94}$.

Podczas swojej audiencji publicznej Marescotti przemawiał na siedząco ${ }^{95}$. Według diariuszy mowa ta trwać miała około kwadransa ${ }^{96}$, choć z uwagi na długość znanego i wielokrotnie przedrukowywanego tekstu Oratio nuncjusza wydaje się, że była to raczej około półgodzinna wypowiedź. Językiem wygłoszonej mowy była oczywiście łacina. Autorzy

92 D. Gregorowicz, Tiara, s. 95-110.

93 AAV. Segr. di Stato, Polonia 83, k. 183-186r, Oratio Habita in regia electionis Comitiis ab Archiepiscopo Corinthi Nuntio Apostolico Varsavia die 4 Junii 1669.

94 F. Wolański, Sapiehowie w świetle funeralnego dyskursu kaznodziejskiego epoki saskiej. Rekonesans badawczy, w: Wielkie rody dawnej Rzeczypospolitej XVI-XIX wieku, t. 1, Sapiehowie, red. T. Ciesielski, M. Sawicki, Opole 2018, s. 440.

95 BK, rkps 365, k. 14v, Connotatio transactionum.

96 F. Hirsch, op. cit., s. 63; BC, rkps 1661, Diariusz sejmu elekcyjnego 1669 r., k. 40. 
niektórych diariuszy sejmowych podkreślili, iż nuncjusz wyrecytował ją z pamięci i z dużą dozą retorycznych umiejętności ${ }^{97}$.

Według relacji samego Marescottiego, oracji wysłuchać miało z uwagą około 10 tys. szlachty ${ }^{98}$. Autor jednego z diariuszy pisze nawet o kilkunastu tys. zgromadzonych ${ }^{99}$. Odpowiedzi na wystąpienie nuncjusza udzielili po raz kolejny prymas Prażmowski (w imieniu senatu) oraz marszałek sejmu Potocki (w imieniu zgromadzonej szlachty). Prażmowski, eleganti et culto stylo ${ }^{100}$, zapewnił papieskiego dyplomatę o lojalności Rzeczypospolitej w stosunku do Stolicy Apostolskiej, nieustającej wdzięczności za doprowadzenie do konwersji średniowiecznego państwa Piastów, a później jagiellońskiej Litwy na katolicyzm, a następnie za wielowiekową opiekę nad Kościołem polsko-litewskim, szczególnie w czasach reformacji. Docenił ponadto dotychczasowe papieskie zaangażowanie wobec wydarzeń bezkrólewia nastałego w wyniku abdykacji Jana Kazimierza Wazy i błogosławieństwo dla pomyślnego wyboru katolickiego monarchy. W podobnym tonie, choć dużo zwięźlej (wg. relacji Chrapowickiego „ledwo słów ze 20 i to frigidissime"101), wypowiedział się marszałek sejmu Potocki, dziękując za wystąpienie papieskiego dyplomaty, wyrażając w imieniu zgromadzonej szlachty wdzięczność za papieską opiekę i obiecując elekcję księcia katolickiego. Obszedł on wcześniej (co warte podkreślenia: wbrew panującym dotychczas zwyczajom) wszystkie województwa, apelując do szlachty o formalne ustosunkowanie się do przedstawionego przez nuncjusza stanowiska Stolicy Apostolskiej.

Marescotti wysłuchał odpowiedzi na swoje wystąpienie w pozycji siedzącej, następnie wstawszy, pokłonił się i w tym samym orszaku co poprzednio, choć „zz mniejszą asystencją"102, przy dźwiękach bębnów i trąb został odprowadzony do swojej warszawskiej rezydencji ${ }^{103}$. Nale-

97 BC, rkps 408, k. 94v, Diariusz Elekcji Króla Jegomości Michała; BC, rkps 408, k. 573v, Diariusz Elekcji Króla Michała.

98 Vademecum, s. 71; AAV, Arch. Nunz. di Varsavia 174, k. 105r, Breve relatione dell'Udienza publica.

99 BK, rkps 365, k. 14v, Connotatio transactionum.

100 BC, rkps 408, k. 573v, Diariusz Elekcji Króla Michała.

101 J.A. Chrapowicki, op. cit., s. 499. Por. BC, rkps 408, k. 573v, Diariusz Elekcji Króla Michała.

102 BK, rkps 316, k. 316v, Diariusz sejmu electionis 1669.

103 Szczegółowy opis audiencji i jej okoliczności został odtworzony na podstawie: Opisanie elekcyi, s. 355-356; F. Hirsch, op. cit., s. 63; Vademecum, s. 68-72; J.A. Chrapowicki, op. cit., s. 498-499; AAV, Arch. Nunz. di Varsavia 174, k. 102-108, Breve relatione dell'Udienza publica; ASV, Segr. di Stato, Polonia 83, k. 178-182, Avviso di Varsavia, 5 VI 1669; ASV, Segr. di Stato, Polonia 83, k. 197, Avviso di Varsavia, 5 VI 1669; AAV, Segr. di Stato, Avvisi 115, k. 111v, Avviso di Varsovia, 4 VI 1669; BAV, Barb. lat. 6371, k. 205v-206, Avvisi 16681669, Varsavia, 4 VI 1669; BC, rkps 164, k. 203-204, Diariusz Wolnej Elekcji; BC, rkps 404, 
ży podkreślić, że według relacji autora jednego z diariuszy sejmowych planowana na godzinę 14 audiencja dość mocno przeciągnęła się w czasie, bo dopiero „o siódmej już był legat przyjechał"104 na pole elekcyjne. Posłuchanie reprezentanta Stolicy Apostolskiej odbyło się zatem w ciągu długiego czerwcowego wieczora, kończąc się po godzinie 21. Nuncjusz "mrokiem aż odprowadzony"105 został następnie do Leszna. Jak podaje jeden z diariuszy, ,"Senat też jako i całe koło rycerskie in summa multitudine Nobilitatis rozjechali się przed samym wieczorem"106.

Zarówno treść brewiów Klemensa IX, jak i oracji nuncjusza Marescottiego, została następnie rozpowszechniona pośród szlachty całej Rzeczypospolitej w postaci rękopiśmiennych i drukowanych kopii, których pierwotną dystrybucją zajmowała się kancelaria nuncjatury. Praktyka ta była utartym zwyczajem już od czasu pierwszych wolnych elekcji i ściśle wiązała się z ograniczeniami przestrzennymi dla bezpośredniej partycypacji zgromadzonej na elekcji szlachty $\mathrm{w}$ audiencji publicznej nuncjusza apostolskiego (choć trzeba zaznaczyć, że podczas posłuchania reprezentanta Stolicy Apostolskiej na polu elekcyjnym frekwencja była zdecydowanie wyższa niż $w$ pozostałych dniach obrad $\left.{ }^{107}\right)$. Czyniono to ponadto $\mathrm{z}$ myślą o tych, którzy z różnych powodów na sejm nie dotarli. Pomimo że mowa dyplomatyczna była klasycznym przykładem przekazu oralnego, a jej drukowane i rozpowszechniane następnie kopie przybierały charakter przekazu piśmiennego, stanowiły one jednak o silnym oddziaływaniu wtórnym przedstawionego w oracji komunikatu.

\footnotetext{
k. 90-91, Diariusz Sejmu Elekcji; BC, rkps 408, k. 151, Diariusz Elekcji Króla Jegomości Michała; BC, rkps 408, k. 572v-573v, Diariusz Elekcji Króla Michała; BC, rkps 1661, k. 40 41, Diariusz sejmu elekcyjnego 1669 r.; BK, rkps 316, k. 316v-317r, Diariusz sejmu electionis 1669; BK, rkps 365, k. 14-16, Connotatio transactionum; BK, rkps 1368, k. 105v, Diariusz wolnej elekcji; BK, rkps 1368, k. 115v, Diariusz Sejmu elekcji króla Michała; BO, rkps 239/ III, k. 42, Diariusz sejmu elekcyjnego; BO, rkps 3564, k. 438v-439, Actus Electionis.

${ }^{104}$ BO, rkps 3564, k. 439r, Actus Electionis.

105 BK, rkps 1368, k. 115v, Diariusz wolnej elekcji. Por. BC, rkps 164, k. 204, Diariusz

Wolnej Elekcji; BC, rkps 404, k. 90, Diariusz Sejmu Elekcji.

106 BK, rkps 365, k. 16v, Connotatio transactionum.

107 M. Chmielewska, op. cit., s. 203; D. Gregorowicz, Tiara, s. 248.
} 


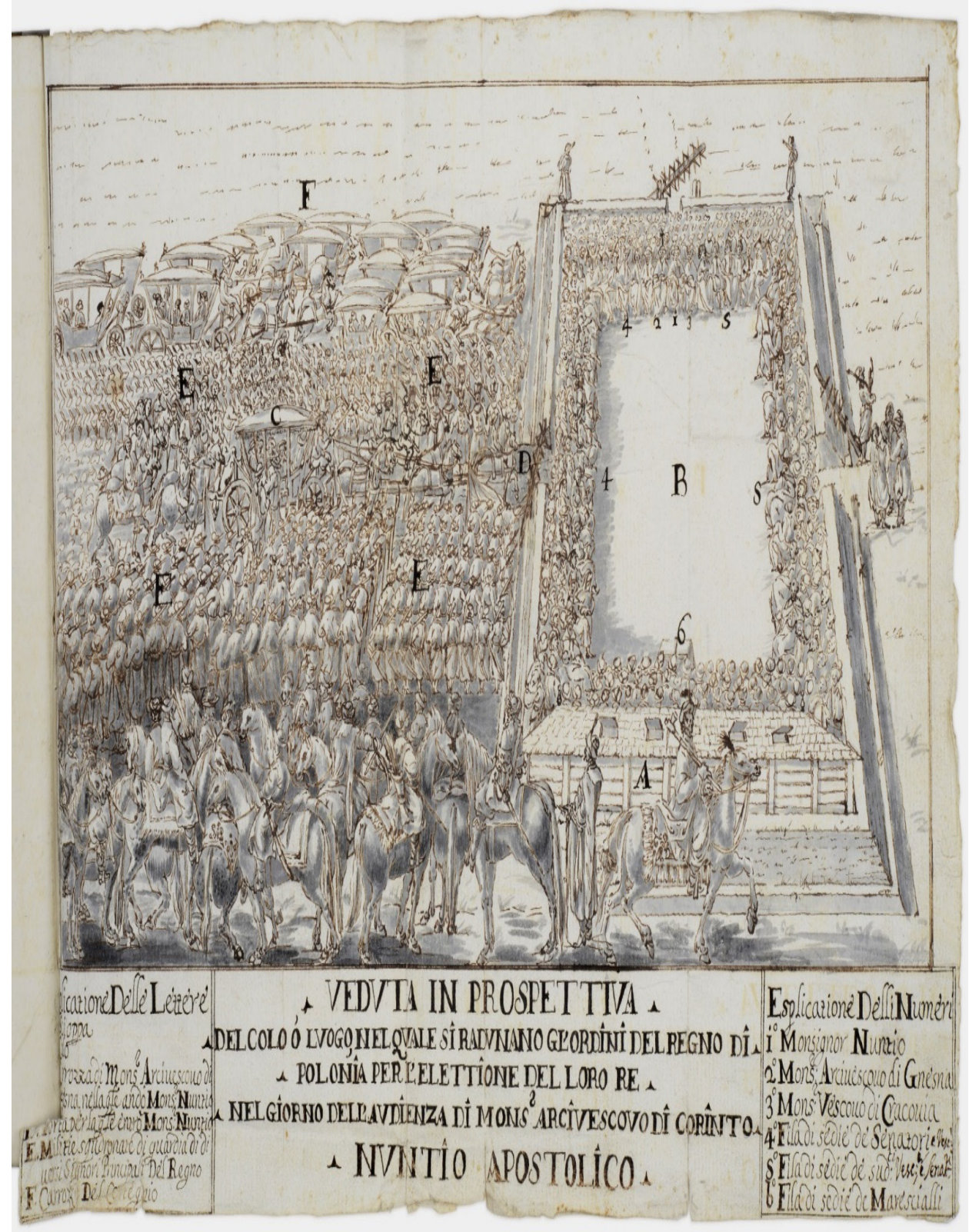

Ryc. 1. Widok pola elekcyjnego podczas audiencji publicznej nuncjusza apostolskiego Galeazza Marescottiego, w dniu 4 VI 1669 r.

Źródło: AAV, Segr. di Stato, Polonia 83, k. 209r, Veduta in prospettiva del colo, o luogo, nel quale si radunano gl'Ordini del Regno di Polonia per l'elettione del loro Re, nel giorno dell'audienza di Mons. Arcivescovo di Corinto Nuntio Apostolico. 


\section{PODSUMOWANIE}

Wszystkie obecne na sejmach elekcyjnych w nowożytnej Rzeczypospolitej poselstwa zagraniczne miały prawo do wygłoszenia mowy poparcia dla własnych lub faworyzowanych przez poszczególne dwory kandydatów. Dyplomaci papiescy tradycyjnie występowali jako pierwsi, korzystając ze swojej ceremonialnej precedencji, przywileju przedstawicieli Stolicy Apostolskiej, wywodzącego się bezpośrednio ze średniowiecznej tradycji papieskiego uniwersalizmu ${ }^{108}$. W barokowym świecie XVII w. rytuał stanowił swoistą regułę gwarantującą określony porządek, zasady zachowania oraz kreację tożsamości społecznej i politycznej. W przypadku audiencji dyplomatów papieskich celebra stanowiła ponadto odbicie wciąż silnego majestatu i władzy głowy Kościoła ${ }^{109}$.

Swoje wystąpienie na sejmie elekcyjnym 1669 r. nuncjusz Marescotti przedstawiał w bieżących raportach wysyłanych do Rzymu jako uwieńczone sukcesem, pisząc, że audiencja publiczna non poteva seguire con maggior decoro, et applauso ${ }^{110}$, a także, iż oracja została wysłuchana przez zgromadzonych con inesplicabile attentione ${ }^{111}$. „Legat miał mowę piękną i łaciną wyborną cum benedictione, nie przyczyniając się za żadnym kon-

108 M. Boiteux, Parcours rituels romains à l'èpoque moderne, w: Cérémonial, s. 29. Ordum regulujące dyplomatyczną precedencję zostało sformalizowane w 1504 r., w czasie trwania pontyfikatu Juliusza II. Zob. M.A. Visceglia, Il cerimoniale come linguaggio politico, w: Cérémonial, s. 126. Prestiż reprezentacji dyplomatycznych Stolicy Apostolskiej został następnie potwierdzony przez bullę Pastor aeternus, wydaną przez Leona X w $1516 \mathrm{r}$. Zob. M.S. Anderson, The Rise of Modern Diplomacy 1450-1919, London-New York 1993, s. 17; A. Hugon, Rivalités européennes et hégémonie mondiale, XVIe - XVIII siècle, Paris 2002, s. 55; P. Wandycz, Dyplomacja, w: Cywilizacja europejska: eseje i szkice z dziejów cywilizacji i dyplomacji, red. M. Koźmiński, Warszawa 2010, s. 187. Pierwszeństwo przedstawicieli dyplomatycznych papiestwa uznawano na wszystkich katolickich dworach, w tym oczywiście w Rzeczypospolitej, gdzie szlachta była wyjątkowo przywiązana do niuansów ceremonialnych. Zob. S.E. Nahlik, Narodziny nowożytnej dyplomacji, Wrocław-Warszawa 1971, s. 120; H.D. Wojtyska, Papiestwo - Polska, 1548-1563, Lublin 1977, s. 229-231; S. Andretta, op. cit., s. 209-210; D. Gregorowicz, Tiara, 247-249. O szczególnej pozycji nuncjusza apostolskiego i jego pierwszeństwie w dostąpieniu audiencji publicznej na sejmie elekcyjnym w Rzeczypospolitej pisał w swoim dziele dotyczącym ceremoniału dworskiego J.C. Lünig (Theatrum ceremoniale historico-politicum, oder Historisch- und politischer Schau-Platz aller Ceremonien, welche so wohl an europäischen Höfen als auch sonsten bey vielen illustren Fällen beobachtet worden, t. 2, Leipzig 1720, s. 7), zob. J. Kodzik, Ceremoniat polskiego dworu królewskiego w XVII wieku z perspektywy niemieckich uczonych, Warszawa 2015, s. 149-150.

${ }_{109}$ M. Boiteux, op. cit., s. 27-29.

110 AAV, Segr. di Stato, Polonia 83, k. 194r, Avviso di Varsovia, 5 VI 1669.

111 AAV, Segr. di Stato, Polonia 83, k. 179v, Avviso di Varsovia, 5 VI 1669. 
kurentem"112 - relacjonował natomiast w swoim diariuszu Chrapowicki, podkreślając natomiast tak mile widzianą w Rzeczypospolitej neutralność reprezentanta Stolicy Apostolskiej. Barzo culté113 - określili orację nuncjusza autorzy innych diariuszy. Jedno z awiz uwypukliło ponadto fakt, że nawet niekatolicka szlachta z uwagą i z respektem przysłuchiwała się wypowiedzi papieskiego dyplomaty ${ }^{114}$. W istocie, mowa nuncjusza apostolskiego na sejmach elekcyjnych w Rzeczypospolitej stanowiła zwykle „wystąpienie w połowie drogi pomiędzy retorycznym pięknem tak cenionym przez humanistów, a cechami dyskursywnymi wymaganymi w negocjacjach politycznych"115. Była to zatem oracja o charakterze politycznym, przybierała jednak niektóre cechy komunikatu kaznodziejskiego, w którym „przenikały się dwie perspektywy ukazywania społeczeństwa Rzeczypospolitej: pierwsza - skoncentrowana na szlachcie i jej apologii oraz druga - prezentująca wizję społeczeństwa i jego stratyfikacji, dla celów pragmatycznych, jako symbol wykorzystywany do promowania uniwersalnych wartości chrześcijańskich” 116. „Oprócz swej właściwej funkcji dyplomatycznej była ona także nie lada widowiskie$\mathrm{m}^{\prime \prime 117}$ - napisała o audiencji papieskiego dyplomaty autorka monografii sejmu elekcyjnego Michała Korybuta Wiśniowieckiego, Chmielewska. Należy w tym miejscu podkreślić, że głównym zadaniem wystąpienia nuncjusza na sejmie elekcyjnym nie było $\mathrm{w}$ zasadzie wygłoszenie samej mowy, ale uroczyste przekazania papieskich brewiów: osobno dla senatorów i dla młodszej braci. W przypadku sejmu elekcyjnego 1669 r. i misji Marescottiego także realizacja tego zadania odbyła się bez przeszkód, a listy Klemensa IX spotkały się z ciepłym przyjęciem ze strony szlachty.

Nuncjusz podkreślał w swoich relacjach życzliwe traktowanie jego osoby w czasie całego sejmu elekcyjnego. Nawet prymas Prażmowski, z którym Marescotti pozostawał w nienajlepszych relacjach przez cały okres bezkrólewia, odwiedził go w czasie trwania obrad $\mathrm{z}$ bogatym orszakiem, okazując życzliwość. W trakcie trwania sejmu elekcyjnego nuncjusz stale przebywał w swojej warszawskiej rezydencji, mieszczącej się na terenie jurydyki Leszno. Swobodnie poruszał się jednak po

112 J.A. Chrapowicki, op. cit., s. 499.

113 BC, rkps 408, k. 151v, Diariusz Elekcji Króla Jegomości Michała; BC, rkps 408, k. 573v, Diariusz Elekcji Króla Michała.

114 AAV, Segr. di Stato, Polonia 83, k. 197, Avviso di Varsovia, 5 VI 1669.

115 I. Lazzarini, Communication and Conflict, Italian Diplomacy in the Early Renaissance, 1320 1520, Oxford 2015, s. 192: „Performance midway between the rhetorical embellishments so prized by humanists and the discursive resources required by a political negotiation".

${ }^{116}$ F. Wolański, op. cit., s. 439-440. Zob. J.A. Drob, Model człowieka wieku XVII w kazaniach Bernarda Gutowskiego, „Roczniki Humanistyczne” 1981, 29, 2, s. 75-140.

117 M. Chmielewska, op. cit., s. 203. 
stolicy, prowadząc rozmowy polityczne, tak z reprezentantami polsko-litewskiej sceny politycznej, jak i z przedstawicielami obcych ambasad. W przypadku elekcji 1669 r. papieska neutralność wobec wyboru nowego monarchy w Rzeczypospolitej nie była raczej poddawana w wątpliwość. Obecność papieskiego dyplomaty nie wywoływała protestów żadnej z fakcji, a już tym bardziej nikt nie postulował wydalenia reprezentanta Stolicy Apostolskiej z Rzeczypospolitej na czas bezkrólewia ${ }^{118}$. W tym kontekście nuncjusz uważał, iż było to: „powszechnie przyjętym wobec nuncjuszy apostolskich, nie będąc oni traktowani jak ambasadorowie innych książąt, którym nie wolno wjeżdżać do Polski, jeśli nie na kilka dni przed sejmem elekcyjnym, oraz którym rezydencje przyznawane są w miejscowościach o kilka lig odległych od miasta [Warszawy], przy obstawie reprezentantów szlachty"119. W rzeczywistości jednak, pod względem ceremoniału, audiencja dyplomaty Stolicy Apostolskiej niewiele różniła się od posłuchań innych dyplomatów. Bezpośrednie porównanie odnajdujemy $\mathrm{w}$ jednym $\mathrm{z}$ diariuszy sejmowych, przy opisie audiencji udzielonej w dniu 7 czerwca 1669 r. ambasadorowi cesarskiemu Schaffgotschowi, „którego wjazd takimże sposobem eadem ceremonia et splendore jako i Jego Mości Księdza Nuncjusza Posła od Ojca Świętego [był] przyozdobiony"120.

Należy podkreślić, że Marescotti nie wziął udziału w żadnych obrzędach liturgicznych towarzyszących tradycyjnie obradom sejmu elekcyjnego, a nawet $\mathrm{w}$ inauguracyjnej mszy do Ducha św. Nuncjusz usprawiedliwiał swoją nieobecność faktem, że biskupi występowali podczas tych uroczystości nie jako reprezentanci episkopatu, ale jako senatorzy stanowiący corpo della Republica ${ }^{121}$. Rzeczywistym powodem absencji Marescottiego musiała być jednak jego rywalizacja na tle ceremonialnym z prymasem Prażmowskim, który jak ognia unikał partycypowania w tych samych

118 AAV, Segr. di Stato, Polonia 83, k. 182, Avviso di Varsovia, 5 VI 1669. Warto podkreślić, że w XVI w. obecność dyplomaty papieskiego na elekcji niejednokrotnie wzbudzała w wielowyznaniowej Rzeczypospolitej protesty. Zob. D. Gregorowicz, Tiara, s. 218-233.

119 AAV, Segr. di Stato, Polonia 83, k. 182, Avviso di Varsovia, 5 VI 1669: „È sempre stato pratticato con li Nuntii Apostolici, non caminando essi al pari de gli Ambasciatori de gli altri Prencipi, a' quali non è permesso di portarsi in Polonia che pochi giorni prima della Dieta d'elettione, e gli vengono assegnati li quartieri in ville alcune leghe lontane da questa Città, con assistenza di alcuni Nobili".

120 BC, rkps 408, k. 577r, Diariusz Elekcji Króla Michała.

121 Vademecum, s. 53; AAV, Arch. Nunz. di Varsavia 174, k. 107r, Breve relatione dell'Udienza publica; AAV, Segr. di Stato, Polonia 83, k. 180r, Avviso da Varsavia, 5 VI 1669 . 
uroczystościach co nuncjusz ${ }^{122}$. Reprezentant Stolicy Apostolskiej, w perspektywie kontynuacji swojego urzędowania w Rzeczypospolitej u boku nowego monarchy, nie chciał dodatkowo zaostrzać i tak już napiętych relacji z arcybiskupem gnieźnieńskim.

Propaganda Stolicy Apostolskiej wielokrotnie starała się podkreślać rolę działalności własnej dyplomacji dla pomyślnego i zgodnego wyniku elekcji 1669 r. Jedno z awiz wywodzące się ze środowiska nuncjatury w Rzeczypospolitej podaje: „Elekcja Jego Królewskiej Mości była naprawdę niezwykłą nie tylko dlatego, że przez ponad 800 lat nie udawało się Polsce posiąść króla narodowego, ale dlatego, że była zupełnie nieprzewidziana. Stąd wszyscy przypisują ją Bożej Opatrzności, przywołanej gorliwymi modlitwami czynionymi i nakazywanymi w tym celu przez Najwyższego Papieża oraz żarliwymi ojcowskimi napomnieniami dokonanymi przez Jego Świątobliwość na sejmie, za pisemnym pośrednictwem jego brewiów i poprzez głos Monsiniora nuncjusza apostolskiego"123. Sam Michał Korybut Wiśniowiecki potwierdzać miał to stanowisko i wyrażać swą wdzięczność za zaangażowanie Klemensa IX i jego dyplomacji w sprawy elekcji ${ }^{124}$. W rzeczywistości aktywność polityczna nuncjusza na elekcji 1669 r. sprowadzała się przede wszystkim do przeciwdziałania ewentualnym aspiracjom moskiewskim do polsko-litewskiego tronu, a także do prób wyciszania wewnętrznych konfliktów międzyfakcyjnych okresu interregnum.

Obecność Stolicy Apostolskiej na sejmie elekcyjnym wiązała się nie tylko z uznaną rolą papieża jako głowy Kościoła, ale stanowiła zarówno dla Rzymu, jak i dla szlacheckiego gremium Rzeczypospolitej, wyraz przynależności do „międzynarodowej” społeczności ówczesnej Europy. W drugiej połowie XVII w. było to szczególnie ważne ze względu na obopólną (zarówno papiestwa, jak i państwa polsko-litewskiego) stopniową degradację pozycji politycznej.

${ }^{122}$ D. Gregorowicz, Primate, s. 49.

${ }^{123}$ AAV, Segr. di Stato, Polonia 83, k. 212r, Avviso da Varsavia, 26 VI 1669: „L'assuntione di Sua Maestà è stata veramente prodigiosa, non solo perché da ottocento e più anni in qua non è riuscito alla Polonia l'haver un Re nationale, ma perché non è stata neppur premeditata. Onde non vi è chi non l'ascriva a puro effetto della Providenza Divina, eccitata dalle fervorose orationi fatte, et ordinate a tal'effetto dal Sommo Pontefice, e dalle viscerate paterne esoratationi fatte da Sua Beatitudine a questa Dieta in scritto per mezzo de' suoi Brevi, et in voce per mezzo di Mons. Nuntio Apostolico".

${ }^{124}$ Ibidem. 


\title{
REFERENCES (BIBLIOGRAFIA)
}

\author{
Manuscripts (Rękopisy) \\ Archivio Apostolico Vaticano: \\ Segreteria di Stato: Avvisi 115; Polonia 82, 83, 182. \\ Archivio Nunziatura di Varsavia 174. \\ Biblioteca Apostolica Vaticana: \\ Barberiniani latini 6471. \\ Biblioteka Książąt Czartoryskich: \\ rkps 164, 404, 408, 1661. \\ Biblioteka Kórnicka PAN: \\ rkps 316, 365, 1368. \\ Biblioteka Zakładu Narodowego im. Ossolińskich: \\ rkps 239/III, 3564.
}

\section{Printed sources (Źródła drukowane)}

Bragaccia G., L'ambasciatore, Padova 1627.

Chrapowicki J.A., Diariusz. Cz. 2, Lata 1665-1669, oprac. A. Rachuba, T. Wasilewski, Warszawa 1988.

Elementa ad Fontium Editiones, t. 3, Repertorium rerum polonicarum ex Archivo Orsini in Archivo Capitolino Romae, I pars, wyd. W. Wyhowska de Andreis, Romae 1961.

Fantuzzi G., Diariusz podróży po Europie (1652), oprac. i tłum. W. Tygielski, Warszawa 1990.

Hirsch F., Zur Geschichte der polnischen Königswahl von 1669. Danziger Gesandtschaftsberichte aus den Jahren 1668 und 1669, "Zeitschrift des Westpreußischen Geschichtsvereins" $1889,25$.

Lünig J.C., Theatrum ceremoniale historico-politicum, oder Historisch- und politischer Schau-Platz aller Ceremonien, welche so wohl an europäischen Höfen als auch sonsten bey vielen illustren Fällen beobachtet worden, t. 2, Leipzig 1720.

Relacye nuncyuszów apostolskich i innych osób o Polsce od roku 1548 do 1690, t. 2, wyd. E. Rykaczewski, Berlin-Poznań 1864.

Vademecum pro nuntiis apostolicis in Polonia a Galeazzo Marescotti, Nuntio Apostolico, circa a. 1670 exaratum, quod apud Ciampi inscribitur L'istruzione al nuovo Nunzio di Polonia, wyd. A. Kakowski, Petropoli 1912.

Vetera monumenta Poloniae et Lithuaniae gentiumque finitimarum historiam illustrantia, t. 3, 1585-1696, wyd. A. Theiner, Roma 1863.

\section{Studies (Opracowania)}

Anderson M.S., The Rise of Modern Diplomacy 1450-1919, London-New York 1993.

Andretta S., Cerimoniale e diplomazia pontificia nel XVII secolo, w: Cérémonial et rituel à Rome: (16. ${ }^{\circ}-19 .^{\circ}$ siécle), red. M.A. Visceglia, C. Brice, Roma 1997.

Bély L., Souveraineté et souverains: la question du cérémonial dans les relations internationales à l'époque modern, „Annuaire-Bulletin de la Société de l'histoire de France” 1993.

Boiteux M., Parcours rituels romains à l'èpoque moderne, w: Cérémonial et rituel à Rome: (16. 19. ${ }^{\circ}$ siécle), red. M.A. Visceglia, C. Brice, Roma 1997.

Caccamo D., Osservatori italiani della crisi polacca a metà del Seicento. La Relazione di S. Cefali e le Replicazioni di C. Masini, "Archivio Storico Italiano" 1974, 71.

Cascioli R., Fantuzzi, Giacomo, w: Dizionario Biografico degli Italiani, t. 44, 1994, https://www. treccani.it/enciclopedia/giacomo-fantuzzi_(Dizionario-Biografico) [dostęp: 1 VI 2020]. 
Chmielewska M., Sejm elekcyjny Michała Korybuta Wiśniowieckiego 1669 roku, Warszawa 2006.

Czermak W., Ostatnie lata życia Jana Kazimierza, w: Ostatnie lata Jana Kazimierza, oprac. A. Kersten, Warszawa 1972.

Dąbrowski J., Senat koronny wobec abdykacji Jana Kazimierza, "Zeszyty Naukowe Uniwersytetu Jagiellońskiego. Prace Historyczne" 2000, 127.

Drob J.A., Model człowieka wieku XVII w kazaniach Bernarda Gutowskiego, „Roczniki Humanistyczne" 1981, 29, 2.

Fitych T., Personel i organizacja nuncjatury Giovanniego Battisty Lancellottiego 31-szego posta apostolskiego w Polsce (1622-1627), „Saeculum Christianum: pismo historyczno-społeczne" 2001, 8, 1.

Fitych T., Struktura i funkcjonowanie nuncjatury Giovanniego Battisty Lancellottiego (16221627), Opole 2005.

Gregorowicz D., Primate Mikołaj Prażmowski and the Unwelcome Papal Legation in Poland-Lithuania (1668-1669), „Legatio: the Journal for Renaissance and Early Modern Diplomatic Studies" 2018, 2.

Gregorowicz D., Stolica Apostolska wobec abdykacji Jana Kazimierza, „Kronika Zamkowa” $2015,68,2$.

Gregorowicz D., The Role of Papal Diplomats in the Interregnum's Parliamentary Practice of the Polish-Lithuanian Commonwealth (16th-17th centuries), "Dimensioni e problemi della ricerca storica" 2016, 29, 1.

Gregorowicz D., Tiara w grze o koronę. Stolica Apostolska wobec wolnych elekcji w Rzeczypospolitej Obojga Narodów w drugiej połowie XVI wieku, Kraków 2019.

Handke K., Dzieje Warszawy nazwami pisane, Warszawa 2011.

Hugon A., Rivalités européennes et hégémonie mondiale, XVIe - XVIIIe siècle, Paris 2002.

Kłaczewski W., Abdykacja Jana Kazimierza. Społeczeństwo szlacheckie wobec kryzysu politycznego lat 1667-1668, Lublin 1993.

Kodzik J., Ceremoniał polskiego dworu królewskiego w XVII wieku z perspektywy niemieckich uczonych, Warszawa 2015.

Lazzarini I., Communication and Conflict, Italian Diplomacy in the Early Renaissance, 13201520, Oxford 2015.

Marchesani P., La Polonia nei diari di viaggio di Giacomo Fantuzzi, Warszawa 1977.

Matwijów M., Geneza abdykacji Jana Kazimierza Wazy 1662-1668, „Czasopismo Zakładu Narodowego imienia Ossolińskich" 2000, 11.

Matwijów M., Ostatnie sejmy przed abdykacja Jana Kazimierza 1667 i 1668, Wrocław 1992.

Mazzei R., Edycje florenckie i lukańskie w krakowskiej bibliotece w XVII wieku, „Odrodzenie i Reformacja w Polsce" 2011, 55.

Nahlik S.E., Narodziny nowożytnej dyplomacji, Wrocław-Warszawa 1971.

Prodi P., Diplomazia del Cinquecento. Istituzioni e prassi, Bologna 1963.

Ronchi De Michelis L., Masini, Cristoforo, w: Dizionario Biografico degli Italiani, t. 71, 2008, https://www.treccani.it/enciclopedia/cristoforo-masini_\%28Dizionario-Biografico\%29/ [dostęp: 1 VI 2020].

Seredyński W., Sprawa obioru następcy na tron za panowania i po abdykacyi Jana Kazimierza, Kraków 1864.

Skowron R., Ceremoniat przyjęcia ambasadora hiszpańskiego Francisca de Mendozy na warszawskim dworze Wazów w roku 1597, „Kronika Zamkowa” 2017, 70, 4.

Skwarczyński P., Pierwsze trzy wolne elekcje "viritim” 1573-1587, „Teki Historyczne” 1959, 10.

Sowerby T.A., Early Modern Diplomatic History, „History Compass” 2016, $14,9$.

Targosz K., Masini, Krzysztof, w: Polski Słownik Biograficzny, t. 20, Wrocław-Gdańsk 1975.

Tygielski W., Włosi w Polsce XVI-XVII wieku, Warszawa 2005. 
Visceglia M.A., Il cerimoniale come linguaggio politico, w: Cérémonial et rituel à Rome: (16. -19. ${ }^{\circ}$ siécle), red. M.A. Visceglia, C. Brice, Roma 1997.

Wandycz P., Dyplomacja, w: Cywilizacja europejska: eseje i szkice z dziejów cywilizacji i dyplomacji, red. M. Koźmiński, Warszawa 2010.

Wojtyska H.D., Papiestwo - Polska, 1548-1563, Lublin 1977.

Wolański F., Sapiehowie w świetle funeralnego dyskursu kaznodziejskiego epoki saskiej. Rekonesans badawczy, w: Wielkie rody dawnej Rzeczypospolitej XVI-XIX wieku, t. 1, Sapiehowie, red. T. Ciesielski, M. Sawicki, Opole 2018.

\section{NOTA O AUTORZE}

Dorota Gregorowicz - dr, adiunkt w Zespole Badawczym Historii Nowożytnej XVI-XVIII w. Instytutu Historii Uniwersytetu Śląskiego w Katowicach. Jej zainteresowania obejmują stosunki polsko-papieskie w XVI i XVII w., znaczenie i organizację nuncjatury apostolskiej w Rzeczypospolitej, a szerzej zagadnienie nowożytnej komunikacji politycznej w perspektywie nowej historii dyplomacji. 